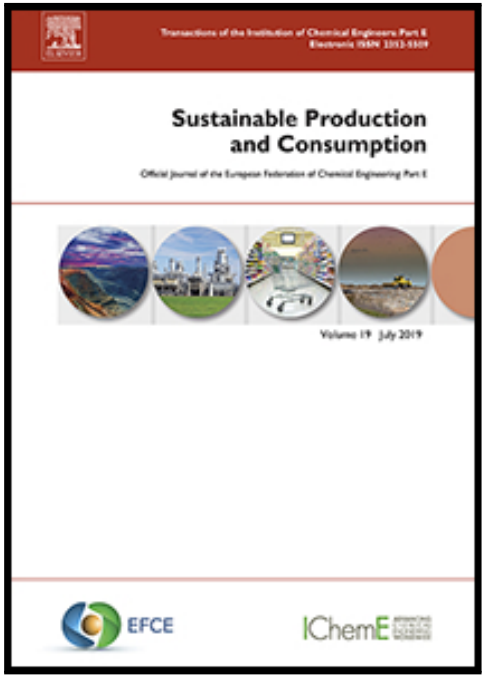

\title{
ENTREPRENEURSHIP AND NATURAL RESOURCE RENTS: EVIDENCE FROM EXCESSIVE ENTREPRENEURIAL ACTIVITY
}

Nguyen Phuc Canh, Bach Nguyen, Su Dinh Thanh, Sangho KIM

PII:

DOI:

Reference:

To appear in:

Received date:

Revised date:

Accepted date:

\section{S2352-5509(20)30368-7}

https://doi.org/10.1016/j.spc.2020.07.010

SPC 352

Sustainable Production and Consumption

29 April 2020

18 July 2020

18 July 2020

Please cite this article as: Nguyen Phuc Canh, Bach Nguyen, Su Dinh Thanh, Sangho KIM , ENTREPRENEURSHIP AND NATURAL RESOURCE RENTS: EVIDENCE FROM EXCESSIVE ENTREPRENEURIAL ACTIVITY, Sustainable Production and Consumption (2020), doi: https://doi.org/10.1016/j.spc.2020.07.010

This is a PDF file of an article that has undergone enhancements after acceptance, such as the addition of a cover page and metadata, and formatting for readability, but it is not yet the definitive version of record. This version will undergo additional copyediting, typesetting and review before it is published in its final form, but we are providing this version to give early visibility of the article. Please note that, during the production process, errors may be discovered which could affect the content, and all legal disclaimers that apply to the journal pertain.

(C) 2020 Published by Elsevier B.V. on behalf of Institution of Chemical Engineers. 
ENTREPRENEURSHIP AND NATURAL RESOURCE RENTS: EVIDENCE FROM EXCESSIVE ENTREPRENEURIAL ACTIVITY

\section{Nguyen Phuc Canh*}

School of Banking, University of Economics Ho Chi Minh City, Ho Chi Minh (700000), Vietnam

(canhnguyen@ueh.edu.vn)

\section{Bach Nguyen}

Aston University, UK \&

University of Economics Ho Chi Minh City, Ho Chi Minh (700000), Vietnam

(b.nguyen1@aston.ac.uk)

\section{Su Dinh Thanh}

School of Public Finance, University of Economics Ho Chi Minh City, Ho Chi Minh (700000), Vietnam

(dinhthanh@ueh.edu.vn)

\section{Sangho KIM}

College of International Management, Ritsumeikan Asia Pacific University, Japan (shkim@apu.ac.jp)

*Corresponding author: Nguyen Phuc Canh, School of Banking, University of Economics Ho Chi Minh City, 59C Nguyen Dinh Chieu, District 3, Ho Chi Minh City, Vietnam, 700000, $+84977405553$

${ }^{* *}$ There is no conflict of interest

Abstract: This study investigates the impact of excessive entrepreneurial activity on natural resource rents. We employ the ecological perspective to argue that while 
entrepreneurship is usually associated with innovation and improved efficiency, and thus reduced natural resource rents, excessive entrepreneurial activity may increase natural resource rents and harm the environment. Investigating a global sample of 70 countries over 11 years (2006-2016) using advanced techniques to address econometric issues, we find initial evidence supporting the natural resource rents of excessive entrepreneurship. We also find heterogeneity between high-income economies (HIEs) and low and middleincome economies (LMEs) as well as between four vital natural resources: coal, gas, forest, and minerals. The findings in this study contribute to the growing literature examining sustainable entrepreneurial ecosystems.

Keywords: Entrepreneurship; excessive start-up; natural resources rents; environment.

JEL code: L26, M13, 013, Q23, N50. 


\section{Introduction}

Entrepreneurship is essential for economic growth (Baumol, 1968, Schumpeter, 1965). This well-established statement, which originated from neo-classical economic theory, implies that more entrepreneurial activity is always better for any economy (Nguyen, 2019, Nguyen et al.). Also, entrepreneurial activity is often found to have strong links with innovation (Fuentelsaz et al., 2018), which plays an important role in securing the long-term survival of the economy by constraining overconsumption and mitigating climate change. However, too much entrepreneurial activity may not be positive, particularly when the number of entrepreneurs exceeds a certain optimal level; Prieger et al. (2016) propose the existence of an optimal level of entrepreneurship in each economy. Entrepreneurial activity, if it exceeds the optimal level, may negatively influence economic growth.

Meanwhile, in another strand of study, the link between economic growth and natural resources has been examined mainly under the "resource curse" hypothesis, which states that nations endowed with abundant natural resources are usually cursed with stagnant economic development (e.g., Africa) (Canh and Thong, 2020). Ben-Salha et al. (2019) provide a model with four explanations for this paradox: (1) the long-term fall of primary product prices; (2) the volatility of commodities price; (3) "Dutch disease"; and (4) institutional weaknesses. This framework helps us understand why excessive natural resources (resource boom) may not always be beneficial to economic growth.

In this respect, recent studies regard opportunistic entrepreneurs (in contrast to social entrepreneurs and sustainable entrepreneurs) as agents that determine the rentseeking of natural resources (Canh et al., 2020). For example, Torvik (2002) shows that natural resources move productive entrepreneurs into rent-seeking activity, lowering national income and welfare. Murphy et al. (1993), Robinson (1994), and Acemoglu (1995) suggest that initial rent-seeking activity reinforces itself by crowding out productive entrepreneurship from the market. An increase in the number of rent-seekers lowers the returns from both rent-seeking and productive entrepreneurship; however, the effect is greater on the returns from productive entrepreneurship. Baland and Francois (2000) 
argue that an increase in natural resources enhances domestic rent-seeking when the initial proportion of agents engaged in rent-seeking is large.

Building on these two strands of literature, our study investigates whether excessive entrepreneurial activity above the optimal level has a negative impact on natural resource rents. The study provides a mechanism through which economic growth from the ecological perspective may be harmed by the presence of too many opportunistic entrepreneurs. The study underscores the point that ecological constraints are a significant problem for economic growth, leading to the need to reconsider the long-held view that the more entrepreneurial activity, the better (Barbier, 2005, Potts et al., 2010).

Specifically, we propose a positive relationship between excessive entrepreneurship and natural resource rents. We acknowledge that entrepreneurship is typically associated with innovation and improved efficiency, and thus contributes to economic growth (Audretsch and Keilbach, 2004). When there are too many small entrepreneurs; however, technological progress stemming from large-scale R\&D and scale economies may suffer; this lowers economic efficiency (Prieger et al., 2016). Severe competition requires economic agents, both newcomers and incumbent firms, to secure every opportunity for survival and growth; this makes entrepreneurs more opportunistic, and they pursue higher natural resource rents as a result.

We test our rent-seeking hypothesis by using a global sample of 70 countries for the period 2006-2016. Our empirical settings allow us to control for all relevant econometric issues and so generate consistent and reliable results. We conduct a set of supplemental analyses on two groups of economies: low and middle-income economies (LMEs) and high-income economies (HIEs). We also analyze four natural resources: coal, gas, forest, and minerals.

Empirically, we find a positive association between excessive entrepreneurial activity and natural resource rents. We also find that the natural rent-seeking of excessive entrepreneurship is stronger in HIEs than in LMEs and that the effects are greater on mineral rents and forest rents than on coal rents and gas rents. Thus, we propose that there 
is an optimal level of entrepreneurship that balances economic growth and environmental protection.

Our study contributes to the relevant literature in three principal ways. First, it is one of the first studies to investigate the relationship between excessive entrepreneurship and natural resource rents systematically. We combine the entrepreneurship literature with the literature on ecological economics to explain the natural rent-seeking of excessive entrepreneurship. Our study subscribes to Prieger et al. (2016)'s proposition that entrepreneurial activity above the optimal level reduces economic growth.

Second, findings in this study extend the emerging strand of research highlighting the importance of sustainable entrepreneurial ecosystems. Following Ludeke-Freund (2020), we suggest that economic growth should not be seen as the sole ultimate goal of entrepreneurship. A sustainable entrepreneurial ecosystem may lead to slower growth rates or even de-growth. However, the social and environmental benefits obtained from such an ecosystem may be worth pursuing (van Lunenburg et al., 2020).

Third, we carefully examine the heterogeneity associated with HIEs and LMEs, as well as the four types of natural resources. Thus, our findings provide a broad perspective on the impact of excessive entrepreneurship on natural resource rents. Finally, our study puts forward useful suggestions for policymakers who seek to find a balance between boosting entrepreneurship and protecting the environment.

We organize this study as follows. In section 2 , we provide the literature review. In section 3, we present the data and the empirical model. In section 4, we first estimate a proxy of excessive entrepreneurship and use the proxy to estimate its impact on natural resource rents. We then discuss the empirical results. In section 5, we conclude the study.

\section{Literature Review}

The relationship between natural resources and entrepreneurial activity is a controversial topic in the extant literature. Previous studies mainly focus on testing the resource curse hypothesis, which mainly revolves around the question "are nations with high resource rents cursed with reduced entrepreneurial activity?" The empirical findings 
against this hypothesis are, unfortunately, mixed and inclusive. For example, Chambers and Munemo (2019) test the hypothesis on 116 countries in the period 2001-2012 and show that nations with substantial natural resource extraction exhibit limited entrepreneurial activity. On the other hand, Ben-Salha et al. (2019), using a sample of top resourceabundant countries in the period 1970-2013, find evidence that the natural resource blessing hypothesis is valid in the long run.

In an endeavour to synthesize the literature, Baland and Francois (2000) propose a theoretical model which states that the influence of natural resources on entrepreneurial activity depends critically on the nature of the equilibrium that existed in the country when resources started to increase. When the initial proportion of agents engaged in entrepreneurship (innovative activities) is large, an increase in the economy's resources increases domestic entrepreneurship. However, when a large proportion of individuals are already engaged in rent-seeking, a resources boom inclines the economy toward more rent-seeking.

Based on previous studies, we argue that resource rent-seeking may increase when there is an excessive number of entrepreneurs in an economy. In other words, when entrepreneurial activity is held at an appropriate level, entrepreneurs will contribute to economic growth by introducing innovations and improving economic efficiency. However, when entrepreneurial activity exceeds the equilibrium level, the forces of competition (among new firms and between new firms and incumbent firms) may outweigh the innovation effect and incentivize entrepreneurs to seek rents from natural resources to gain competitive advantage.

Before establishing the theoretical mechanisms underpinning the expected nonlinear relationship between resource rent and entrepreneurship, we first define natural resources and distinguish natural resource rent from Schumpeterian rent, which are the key concepts of our theoretical framework.

Natural resources are defined by the World Trade Report as "stocks of materials that exist in the natural environment that are both scare and economically useful in the production or consumption, either in their raw state or after a minimal amount of 
processing" (Report, 2010). The notion of rent was developed by Tullok to indicate that an entity seeks to gain added wealth without any reciprocal contribution of productivity (Tullock, 1967). ${ }^{i}$ In this study, we use the term natural resource rent or resource rent to indicate the abuse of natural resources by entrepreneurs seeking private gain (e.g., profits, business survival, or growth) without adequately contributing to the economy by introducing innovations and improving efficiency.

In contrast, Schumpeterian rent, defined as "the additional value that results from a new combination of resources (including new modes of organization) that an entrepreneur may have undertaken" (Sautet, 2013). Schumpeterian rent can be seen as abnormal profits that entrepreneurs earn from their venture activities and is the driving force behind the process of creative destruction (Danneels, 2012). Nonetheless, Schumpeterian rent is transient by nature, in the sense that it arises only in situations of disequilibrium when the economy shifts from the old modes to new modes. Once the market settles into a new equilibrium, these rents disappear (Sautet, 2013).

Entrepreneurs who aim to acquire Schumpeterian rent will try to push the economy out of its current equilibrium by introducing new products to replace older ones. This process of creative destruction is usually associated with innovation, new business models, and improved efficiency, which lead to reduced natural resource rent (Stephan et al., 2015). However, it is noteworthy that, according to ecological economics, production and consumption are fundamentally a linear function of raw material (Chambers and Munemo, 2019, Barbier, 2005) ${ }^{1}$ As such, economic activities will ultimately induce amplified resource rents, i.e., an increase in the contributions (in the absolute values) of coal, mineral, gas, and forest in GDP (Behrens et al., 2007). This amplified resource rent effect may outweigh the creative destruction effect, especially when there is an excessive number of entrepreneurs in an economy, for the following reasons.

First, facing severe competition, entrepreneurs may become more opportunistic and driven by rent-seeking to secure survival and growth opportunities for their business ventures (Prieger et al., 2016). Baumol (2004) emphasizes that entrepreneurship should

${ }^{1}$ Along with other neoclassical factors, such as labour and capital. 
not be equated to virtuous behaviour: "because we recognize that entrepreneurship can bring innovation and growth, we are misled into thinking that it must always contribute to economic abundance and expansion." In fact, the ultimate goal of entrepreneurs is the acquisition and accumulation of wealth, power, and prestige, with innovation used as a primary weapon (Lafuente et al., 2018).

When there are excessive numbers of entrepreneurs, severe competition may significantly increase the marginal costs of capital and labour, leading to reduced profit margins (Prieger et al., 2016, Lafuente et al., 2018). Entrepreneurs are thus incentivized to extract more natural resources (either directly or indirectly), whose marginal cost may increase at a slower pace compared to capital and labour. An example of indirect natural resource-seeking behaviour is that in highly competitive environments, entrepreneurs may seek lower-priced inputs and materials. In response to this pressure, their suppliers may adopt natural rent-seeking strategies to meet the requirements of their clients. The reason for the relatively low marginal cost of natural resources is primarily due to government policies aimed at keeping resources accessible to domestic producers at affordable prices to secure nations' economic health and boost economic development (Haas, 2011).

In such circumstances, entrepreneurs may come up with business models that rely less on high-skilled human capital the cost of hiring employees increases in severe competition) or on low value-added technology (the cost of funding R\&D investments increases in severe competition), and employ lower-priced, easy-accessed natural resources to make profits (Cressy, 1992, Chell, 2000). Thus, seeking rent from natural resources could be regarded as a feasible strategy under situations of acute competition.

The second reason is that excessive entrepreneurship not only affects newcomers but also influences the behaviour of incumbent firms (Bretschger, 2005). With severe competition and a large number of newly-established firms whose operations are more flexible and efficient, incumbent firms may become more opportunistic in resource rentseeking behaviour to secure their market positions (Buenstorf, 2016). Specifically, Prieger et al. (2016) investigating a global sample show that when there are too many small businesses, competition in the economy will suffer, with an attendant loss of efficiency in 
the sense that technological progress stemming from large-scale $R \& D$ will become stagnant. Since R\&D takes time and is associated with substantial opportunity costs, incumbent firms may decide to direct their investments toward short-term, low-cost but resource-consuming technology as a "quick and easy" competition strategy (Wennekers and Thurik, 1999). Thus, following Torvik (2002), we argue that the effects of excessive competition may outweigh the direct positive effects of improved efficiency and innovation.

Third, entrepreneurship is a (novel) production process that needs natural inputs. Excessive entrepreneurial activity will, therefore, lead to the increased usage of natural resources in the economy. Potts et al. (2010) hold an optimistic viewpoint that increasing environmental damage or the onset of an impending ecological collapse may present entrepreneurial opportunities. We, however, argue that negative externalities (e.g., resource rents) cannot be removed entirely by entrepreneurial actions, especially in situations of severe competition (Schumpeter, 1965, Torvik, 2002). The reason is that entrepreneurs, at the individual level, have no incentive to consider the "big picture" of the natural resource extraction in the economy; their ultimate objective is to maximize Schumpeterian rents and leave the issue of negative externalities to their government (McMullen et al., 2008). Also, Estapé-Dubreuil et al. (2016) find that firms focusing too closely on environmental issues (at the same time as social issues) are significantly inferior in attracting financial investors. Thus, entrepreneurs facing fierce competition have a strong motivation to seek natural resource rents. This undesirable behaviour may overshadow their contribution to the economy.

In sum, we expect entrepreneurial activity to exert a non-linear (U-shaped) effect on a nation's natural resource rents. Specifically, there is an optimal level of entrepreneurship in an economy; entrepreneurial activity exceeding this threshold may incentivize economic agents (both new and incumbent) to seek rents from natural resources to secure the survival and growth of their business. 


\section{Data and Empirical Model}

\section{Empirical Model}

Since the aim of this study is to examine the effects of excessive entrepreneurship on natural resources rents, we adopt a baseline empirical model of natural resource rents as follows:

$$
N R R_{i t}=\alpha_{0}+\beta_{1} Y_{i t}+\beta_{1} Y_{i t}^{2}+\beta_{2} \operatorname{Inv}_{i t}+\beta_{3} U r b_{i t}+\beta_{4} \operatorname{Trade}_{i t}+\beta_{5} F D I_{i t}+\varepsilon_{i t}, \quad \text { [1] }
$$

where $N R, Y, I n v, U r b$, Trade and FDI represent natural resource rents, national income, new investments, urbanization and foreign direct investment, respectively.

The baseline model includes economic development $(Y)$ and its vitality (Inv) to account for natural resource rents because economic development is one of the main drivers and economic activities consume natural resources (e.g., Abdulahi et al. (2019)). In terms of social factors, urbanization represents a change in living standards and social structure. Urbanization requires heavy use of natural resources, such as cement, steel, aluminium, and coal, thereby increasing natural resource rents (Shen et al., 2005). Urbanization is usually associated with industrialization processes, which lead to a higher demand for natural resources (Mudakkar et al., 2013). Meanwhile, trade openness and FDI inflows are a proxy for economic integration (Hajzler, 2014, Ndikumana and Sarr, 2019, Phuc Nguyen et al., 2019), which may exert either a negative or positive impact on natural resource rents through the pollution haven or pollution halo hypotheses (Phuc Nguyen et al., 2019). Finally, the square term of the income level is added into the model to control for the environmental Kuznets curve (EKC) hypothesis, which proposes a non-linear relationship between economic development and environmental degradation.

To investigate the influence of excessive entrepreneurial activity on natural resources rents, we add a set of dummy variables (DUM) representing excessive entrepreneurship to the baseline model. The empirical model is as follows: 


$$
N R R_{i t}=\alpha_{0}+\alpha_{1} D U M_{i t}+\beta_{1} Y_{i t}+\beta_{1} Y_{i t}^{2}+\beta_{2} I n v_{i t}+\beta_{3} U r b_{i t}+\beta_{4} O p e n_{i t}+\beta_{5} F D I_{i t}+
$$

$\varepsilon_{i t}[2]$

\section{Data}

We collect the new business density (new registrations per 1,000 people ages 1564) from World Development Indicators (WDIs - World Bank) and take logarithms as a proxy for entrepreneurial activity. This entrepreneurship rate is employed in the next paragraph to estimate the level of excessive entrepreneurship, which is the level of entrepreneurial activity that exceeds the optimal level of entrepreneurship in an economy. We should, in principle, identify the optimal level of entrepreneurship for every economy. Although there is no consensus in the literature on what is the optimal level of entrepreneurship, Prieger et al. (2016) completed one of the most critical studies on this topic, proposing that a country will suffer a "growth penalty" when entrepreneurship deviates from its optimal level. Prieger et al. (2016) put forward the following equation:

$$
y_{i t}=y^{*}{ }_{i t}-\partial\left|\log T E A_{i t-1}-\log T E A^{*}{ }_{i t}\right|+\left(\alpha_{i}+\varepsilon_{i t}\right) \text {, }
$$

in which $i$ and $t$ denote country $i$ in year $t$, respectively; $y$ is national output and $y^{*}$ is national output at optimal entrepreneurship; TEA is total entrepreneurship rate and TEA* is the optimal level of entrepreneurship rate; $\alpha$ is a country-specific term, and $\varepsilon$ is the residual term. From the equation, we can extrapolate the optimal level of entrepreneurship as follows:

$$
\log T E A^{*}{ }_{i t}=\beta_{1} \log T E A_{i t-1}+\beta_{2}\left(y_{i t}-y^{*}{ }_{i t}\right)+\left(\alpha_{i}+\varepsilon_{i t}\right) \text {, }
$$

in which $\left(y_{i t}-y^{*}{ }_{i t}\right)$ represents the output gap in the economic literature (Orphanides and Norden, 2002). To limit the feedback effect from entrepreneurship on economic growth (Galindo and Méndez, 2014), which would lead to the problem of endogeneity, the study further transforms Eq. [4] by using a one-year lag of output gap in empirical estimation:

$$
\log E A^{*}{ }_{i t}=\beta_{1} \log T E A_{i t-1}+\beta_{2}\left(y_{i t-1}-y^{*}{ }_{i t-1}\right)+\left(\alpha_{i}+\varepsilon_{i t}\right)
$$


At this stage, we face a new issue, i.e., the estimation of the output gap, which is one of the most debated topics in the economic literature (Orphanides and Norden, 2002). Therefore, we apply several strategies to estimate output gaps as a way of reducing concerns related to technical biases.

First, we use a traditional way of estimating the log of real GDP for year (time factor) to extract real GDP variable from cyclicality and trend factors (Clark, 1987). In the estimation, the trend series represent long-term development while the cyclicality represents the short-term fluctuation surrounding the long-term trend. That is, the cyclicality (or the residual from this estimation) is divided by its trend to get a standardized percentage, which forms the output gap. This measure of the output gap is then included in Eq. (3) to estimate excessive entrepreneurship. This method is, however, a naïve technique since it only concerns a time-trend over the long-term. So, the study applies a second technique to estimate the output gap by recruiting the Hodrick-Prescott (HP) filter (Hodrick and Prescott, 1997) to estimate the cyclical factor of real GDP and then includes the result into Eq. [3] as the output gap as well. There are criticisms of the HP filter (e.g., see Hamilton (2018)), and so we use it as one of several ways to estimate the output gap and the excessive entrepreneurship activity as a robustness check. Also, we estimate real GDP growth rate with one-year lag and then extract the residual term to divide by the fitted value from the estimations as the third proxy of the output gap.

After the estimation of Eq. [5] with three different proxies of the output gap and the residual terms predicted, we create a set of dummy variables (DUM1, DUM2, DUM3) which represents the existence of excessive entrepreneurship by the rule that if the residual term is positive, the dummy value is 1 , suggesting the existence of excessive entrepreneurship; otherwise, the value is 0 . The logic here is that the fitted value from Eq. [5] is the assumed optimal level of entrepreneurship. As such, if the residual is greater than zero, the actual value of the entrepreneurship rate is higher than the optimal level, indicating the existence of excessive entrepreneurship.

The above methods drawing on Prieger et al. (2016) do not consider other socioeconomic determinants of entrepreneurship (Ramos-Rodríguez et al., 2012, Sasu and Sasu, 
2015, Thai and Turkina, 2014). Thus, the methods might be weak in capturing all the information about entrepreneurial activity. Therefore, in this study, we go further to incorporate a comprehensive list of covariates and estimate the optimal level of entrepreneurship using a stepwise strategy.

We first estimate the entrepreneurship rate with a one-year lag and assume that any variation from its long-term trend is a cyclical factor of entrepreneurship. Then, we estimate the entrepreneurship rate using its one-year lag, as well as the income level (log of real GDP per capita). Previous studies (Dvouletý, 2018, Ramos-Rodríguez et al., 2012, Thai and Turkina, 2014) have concluded that the trend in entrepreneurship is a function of income level, which represents economic development. Our model also includes covariates such as economic growth, unemployment rate, human capital, institutional quality, and economic freedom. These factors are well documented in the extant literature as critical drivers of entrepreneurial activity (Fuentelsaz et al., 2019, Chowdhury et al., 2019, Chambers and Munemo, 2019). Applying the same procedure, we extract the residuals from each estimation and divide by their fitted value obtained from the estimations. The dummy variables (DUM4, DUM5, DUM6) are created following the principle that if the residuals are greater than zero, the value is 1, suggesting the existence of excessive entrepreneurship; otherwise, the value is 0.

\section{[insert Table 1 here]}

Table 1 presents estimates of excessive entrepreneurship. In Model (1), we divide the residual term from Model (1) by real GDP to calculate the output gap in percentage form. In Model (2), we use the output gap from Model (1) as a regressor and predict the residual term from Model (2) to measure the dummy variable (DUM1) of excessive entrepreneurship. DUM1 equals 1 if the residual from Model (2) is greater than 0; otherwise, DUM1 equals $0 .^{2}$

\footnotetext{
${ }^{2}$ The correlation between the log of entrepreneurship density $(-1)$ and output gap (-1) is 0.08 , and the (variance inflation factor) VIF test shows no evidence of multicollinearity $(\mathrm{VIF}<10)$ between the two independent variables in Model (2).
} 
In Model (3), we measure the cyclical factor of real GDP by the cyclical factor from the HP filter for the log of real GDP. We use the residual of Model (3) to measure the dummy variable (DUM2) of excessive entrepreneurship, which equals 1 if the residual from Model (3) is greater than 0. In Model (4), we regress the real GDP growth rate with a oneyear lag and plug its residual into Model (5). In Model (5), we regress the log of entrepreneurship density with a one-year lag and the residual from Model (4). Likewise, we use the residual of Model (5) to measure the dummy variable (DUM3) of excessive entrepreneurship.

In Model (6), we regress the log of entrepreneurship density with a one-year lag. We use the residual of Model (6) to measure the dummy variable (DUM4) of excessive entrepreneurship, which equals 1 if the residual is larger 0 ; otherwise, it equals 0 . In Model (7), we regress the log of entrepreneurship density with a one-year lag and the log of real GDP per capita (one-year lag). Then, we use the residual of Model (7) to estimate the dummy variable (DUM5) of excessive entrepreneurship in the same way. In Model (8), we regress the log of entrepreneurship density with a one-year lag, the log of real GDP per capita (one-year lag), unemployment rate (one-year lag), one-year lag of log of the human capital index (from PWT), one-year lag of the average of six institutional indicators from worldwide governance indicators (World Bank), and one-year lag of the economic freedom index. We use the residual of Model (8) to measure the dummy variable (DUM6) of excessive entrepreneurship.

Of the variables used, real GDP per capita and economic growth rate are collected from WDIs, the human capital index is collected from Penn World Tables 9.1 (PWT), six institutional indicators are collected from (World Bank), and the economic freedom index is collected from the Heritage Foundation. The percentage of total natural resource rents to GDP $(N R R)$ is collected from WDIs. According to the World Bank, the NRR is measured by the difference between the value of production at world prices and total cost of production. That is, the value of natural resources in GDP can represent the increase in prices of natural resource rents and also the higher abuse of natural resources. Even with the increases in prices or abuse of natural resources, any increase in natural resource values in GDP would reflect the higher dependence of the economy on natural resources and can imply a higher 
level of exploitation of natural resources. Gross capital formation (\% of GDP), urban population to total population (\%), total trade value (\% of GDP), foreign direct investment net inflows (\% of GDP) are collected from WDIs to proxy for income level (Income), population density (Popden), capital formation (Cap), urbanization (Urban), trade openness (Trade), and FDI inflows (FDI) respectively.

There are missing data in entrepreneurship density, coal rents, mineral rents, and natural gas rents in several countries including some countries with high natural resources rents such as Gulf Cooperation Council countries. Furthermore, some countries have missing data on other variables. ${ }^{3}$ By matching all variables, we choose the final sample consisting with 70 economies and two subsamples (34 high-income economies [HIEs] and 46 low and middle-income economies [LMEs]) over the period 2006-2016 (see Table A1, Appendix, for the list of countries and data description of two subsamples). All variables, definitions, calculations and data description are presented in Table 1.

\section{[insert Table 2 here]}

\section{Results and Discussion}

Our sample has a large $N$ (70 countries) over a relatively short-time period (20062016). So, the Pesaran's CD test Pesaran (2004) is employed to check the cross-sectional dependence. According to De Hoyos and Sarafidis (2006), cross-sectional dependence in the errors exists in panel-data estimates, which may be due to the presence of common shocks and unobserved components (Robertson and Symons, 2000, Pesaran, 2004). We also expect strong interdependencies in economic factors among countries in this highly integrated gobal economy. De Hoyos and Sarafidis (2006) explain that coefficient estimates of fixed and random effects panel data models are not consistent if there is correlation between regressors and unobserved components that creates interdependencies across cross-sections. In this case, Pesaran (2006) proposed the panel corrected standard errors (PCSE) as an appropriate estimate (De Hoyos and Sarafidis, 2006).

Results obtained from the CD test are incorporated in the last column of Table 1 . The results indicate the existence of cross-sectional dependence in all the variables. In this

\footnotetext{
${ }^{3}$ Upon request, we can provide details about dropped countries and missing data.
} 
context, the panel corrected standard errors model (PCSE) is argued as a robust estimator (Marques and Fuinhas, 2012, Jönsson, 2005, Bailey and Katz, 2011); thus, it is recruited as the primary estimator in this study. Furthermore, we also employ a set of alternative estimators, including feasible generalized least squares (FGLS), pooled OLS, robust pooled OLS, pooled OLS with year effects for robustness check.

More importantly, in this study, we employ techniques to ensure robustness, consistency, and unbiased results. Specifically, each control variable is added to the estimation one by one. The same procedure is applied for the subsamples. Also, we analyze different types of natural resource rents (besides total natural resource rents), including coal rents (CoalR), mineral rents (MineR), natural gas rents (GasR), and forest rents (ForestR).

\section{[insert Table 3 here]}

We report the main empirical results in Table 3, in which the coefficient estimates of ten different models are presented. Model (1) denotes a basic model, including our primary variable of excessive entrepreneurship (DUM1) along with income and its square term. Then, we add other control variables cumulatively to the basic model from Model (2) to (5); this is to check whether our results are subject to multicollinearity due to correlation between the variables. Model (5) represents a full model, including all the control variables. Models (1) to (5) show that estimations are not sensitive to included controls. So, we proceed to check whether empirical results are robust to alternative measures of excessive entrepreneurship in Models (7) to (10). Models (5) to (10) show that estimations are robust in measuring excessive entrepreneurship ${ }^{4}$.

Regarding control variables, income level has a significant positive impact on natural resource rents while its square term has a significant negative impact, confirming the EKC hypothesis. When we investigate coal rents (CoalR), mineral rents (MineR), natural gas rents (GasR), and forest rents (ForestR) separately, we find an inverted U-shaped curve for coal rents. This finding contrasts with other types of rent, with a U-shaped curve for gas

\footnotetext{
${ }^{4}$ We also check the robustness of the results by adding institutional quality as a control variable; the results are consistent and robust. The detailed results are available on request.
} 
rents and forest rents and a decreasing line for mineral rents (see Table A2-3 in Appendix). The inverted U-shape relationship in coal rents might be associated with the U-shape relationship in natural gas. As income increases, a country substitutes less environmentally damaging natural gas for more damaging coal in the production input mix (Stern, 2004, Canh et al., 2019, Phuc Nguyen et al., 2019). Regarding forest and mineral rents, the proportion of these resources in GDP decreases as a country develops from a primary industry-based economy to a manufacturing industry-based economy. However, wood products are demanded more as natural substitutes for plastic or other artificial products in consumption as income further increases.

Urbanization and FDI inflows have significant positive impacts, increasing natural resource rents. In contrast, trade openness has a significant negative impact on natural resource rents.

From now on, we will concentrate our discussion on excessive entrepreneurship. Estimations in Table 3 show significant positive impacts of excessive entrepreneurship, as represented by dummy variables on natural resource rents; this implies that excessive entrepreneurship increases natural resource rents. Our results are robust for all six dummy variables, which are estimated obtained by different strategies. Thus, the results provide strong evidence of the negative impact of excessive entrepreneurship on natural resource rents.

Our results show that excessive entrepreneurial activity incentivizes entrepreneurs to seek natural resource rents; this confirms our presumption that too much entrepreneurial activity may harm the economy. Our results are in line with previous studies. For example, (Baumol, 2004) suggests that the adverse effect of excessive entrepreneurship stems from severe competition among entrepreneurs and between startup firms and incumbent firms. (Prieger et al., 2016) show that technological progress stemming from large-scale R\&D and scale economies may suffer when there are too many small entrepreneurs, lowering economic efficiency.

Too many entrepreneurs in the economy make them more opportunistic in securing survival and growth opportunities. Although our results are surprising, they are 
deep-rooted. Subscribing to Prieger et al. (2016) and Lafuente et al. (2018), we propose that there is an optimal level of entrepreneurship yielding a balance between economic growth and environmental protection.

In this saying, findings in our study echo the thesis of the sustainable entrepreneurship literature, which argues that entrepreneurship does not follow the "more is better" principle. Also, it is important to encourage other types of entrepreneurship, such as social entrepreneurship and sustainable entrepreneurship, whose discovery, creation, and exploitation of opportunities to create future goods and services also sustain the natural and/or communal environment and provide development gain for others (Volkmann et al., 2019). Our findings also imply that to achieve sustainable society and economy, we should approach the concept of entrepreneurship not only from the neoclassical economic viewpoint (which highlights profit maximization) but also from the need to incorporate viewpoints from social science including co-evolution and co-creation (which emphasize collective sustainability).

Now we investigate the relationship between excessive entrepreneurship and natural resource rents for the two subsamples of HIEs and LMEs. Estimations in Table 4 show the significant positive impact of excessive entrepreneurship on natural resource rents in HIEs. However, those in Table 5 show the positive impact but with weaker statistical significance in LMEs, which implies that the natural rent-seeking of excessive entrepreneurship might be much significant in HIEs than in LMEs.

\section{[insert Table 4, 5 here]}

Our results are consistent with Prieger et al. (2016) and suggest that entrepreneurship is close to its optimal level in developed countries, whereas the level of entrepreneurship is much lower than its optimal rate in developing countries. That is, entrepreneurs are not excessive in number in LMEs. As another explanation, LMEs are so diverse in their abundance of natural resources that this produces the insignificance. For example, entrepreneurs do not have access to natural resources in some LMEs. Previous studies show that entrepreneurship heterogeneity among the country groups has not been fully investigated (Behrens et al., 2007). In this respect, this study acknowledges that 
countries possess different entrepreneurship levels depending on the development phase, resulting in different degrees of natural rent-seeking.

\section{Robustness check}

To check the robustness of the empirical results, we first conduct a set of analysis on different types of natural resources, including coal, minerals, gas, and forest. Estimation results for different types of natural resource rents are reported in Table A2, A3, A4, Appendix.

Specifically, Table A2 presents estimations for coal rents and mineral rents. Table A3 and A4 show estimations for natural gas rents, forest rents, and oil rents, respectively. The estimations are consistent with our main findings and confirm the positive relationship between excessive entrepreneurship and natural resource rents. Specifically, the results show a set of consistent positive impacts of excessive entrepreneurship on mineral rents and forest rents, while there is weaker evidence of the effects of excessive entrepreneurship on coal rents and natural gas rents.

These findings indicate that natural resource rents are multidimensional, and entrepreneurs are keen on seeking rents from specific natural resources. Specifically, mineral rents and forest rents are most likely employed by entrepreneurs to build their competitive advantages since these resources are relatively accessible, especially in developing countries (Munasinghe et al., 2019, Elbra, 2013). Also, these two types of natural resources are crucial to many industry and production processes. As such, when the number of entrepreneurial activities exceeds the optimal level, they are keen on abusing these two kinds of resources to establish competitive advantages. Meanwhile, coal and gas are fuel and are strictly controlled by the states with careful management of the supply and demand (Towler et al., 2016, Lin and Liu, 2010). As such, when the number of entrepreneurial activities exceeds the optimal level, they are less likely to abuse these two types of resources. 
Overall, our findings indicate that severe competition requires entrepreneurs to secure every opportunity for survival and growth. The consequence of this behaviour is that entrepreneurs become opportunistic, and they pursue higher natural resource rents as a result. Also, there is evidence that entrepreneurship is close to its optimal level in developed countries, whereas the level of entrepreneurship is much lower than its optimal rate in developing countries. Therefore, the pressure on natural resources rents is more substantial in developed countries than it is in developing countries. Finally, we find that entrepreneurs are more likely to seek mineral rents and forest rents under severe competition leaving coal rents and natural gas rents to a lesser extent.

\section{Conclusions}

Governments usually hold natural resources at an affordable price to support domestic firms. As competition intensifies, the marginal costs of both financial and human capital increase relative to those of natural resources. Firms facing severe competition seek more rent from natural resources as the number of entrepreneurs grows. Increasing natural resource rents harms the environment and economic sustainability. In this context, we investigate the impacts of excessive entrepreneurial activity on natural resource rents at the national level.

We test the proposed hypothesis using a global sample of 70 countries over 11 years (2006-2016) and find consistent evidence supporting the negative effects of excessive entrepreneurship on natural resource rents. Our findings are consistent across different specifications and estimation methods.

Our study makes three important contributions to the existing literature on ecological entrepreneurship. First, the study proposes that there is an optimal level of entrepreneurship which yields a balance between economic growth and environmental protection. Second, this study shows that the natural rent-seeking of excessive entrepreneurship is more significant in HIEs than in LMEs. Third, this study suggests that natural resource rents are multidimensional, and entrepreneurs prefer rents from specific resources among coal, minerals, gas, and forest. 
Besides these contributions to ecological entrepreneurship, this study is also relevant to the literature examining sustainable and social entrepreneurship. Given that (too much) opportunistic entrepreneurship may boost natural resource rents and harm the environment, it is essential to encourage sustainable and social entrepreneurship that incorporate sustainability into their development ideology. While social entrepreneurship aims to solve social problems, sustainable entrepreneurship is more concerned with natural and environmental issues (Tiba et al., 2019). Unfortunately, the extant literature focuses more on explaining the precedents of creating social/sustainable businesses rather than examining their impact on the economy and society (Arru, 2020, Bischoff, 2019). Future studies may thus seek to investigate the relationship between sustainable entrepreneurship and natural resource rents or environmental protection. Understanding the contributions of sustainable entrepreneurship helps underpin its importance in mainstream literature.

The findings of this study are most relevant to policymakers concerned with boosting entrepreneurship while balancing environmental protection. Authorities should be aware of the existence of the optimal level of entrepreneurship. Excessive entrepreneurial activity adversely affects the sustainability of economic development since it incentivizes natural resource rent-seeking that harms the environments. In this sense, we recommend that policymakers focus on encouraging innovative and productive activities. By selectively supporting high value-added entrepreneurship, authorities can signal that not all venture activities are welcome; this will reduce unnecessary competition and moderate rent-seeking behaviour. Also, our findings imply that policymakers should consider the heterogeneity of types of natural resources and the levels of economic development when identifying the desired levels of entrepreneurship.

This study focuses on the impact of excessive entrepreneurship on natural resources rents, which are an important component of environmental resilience. The study indicates several research directions for future studies. First, new business density used in the study may be too broad and goes far beyond any definition of entrepreneurship activity. Specifically, there are differences in the characteristics of entrepreneurship 
activities, i.e. high-tech entrepreneurship versus low-tech, profit-driven entrepreneurship versus sustainable entrepreneurship, or formal versus informal entrepreneurship.

The investigations on the impact of these different types of entrepreneurship will enrich the literature. Unfortunately, the data from the World Bank on entrepreneurship density is the best available, which limits further investigations. Second, future studies can expand concerns about the impact of excessive entrepreneurship activity to other aspects of the economy, such as environmental protection, social inequality and individual happiness. It would be of valueaable to consider the influence of excessive entrepreneurship activity on the survival of the economy in terms of these factors.

Our study presents a starting point for the literature of entrepreneurship and natural resources economics about the linkages between two factors. Further, the study offers a reflection on the balance between entrepreneurial activities and the need to protect natural resources in future studies. We challenge the long-lasting assumption that entrepreneurship is always good. Future studies might want to explore more about the "dark side" of entrepreneurship to yield relevant policy implications relating to boosting environments. This strand of research would make significant contributions to the literature of sustainable development.

\section{Declaration of interests}

$\bigotimes$ The authors declare that they have no known competing financial interests or personal relationships that could have appeared to influence the work reported in this paper.

\section{Acknowledgement}

Authors are thankful for insightful comments and helpful suggestions from two anonymous reviewers and Editor. All remaining error(s) are our own. 


\section{References}

ABDULAHI, M. E., SHU, Y. \& KHAN, M. A. 2019. Resource rents, economic growth, and the role of institutional quality: A panel threshold analysis. Resources Policy, 61, 293-303.

ACEMOGLU, D. 1995. Reward structures and the allocation of talent. European Economic Review, 39, $17-$ 33.

ARRU, B. 2020. An integrative model for understanding the sustainable entrepreneurs' behavioural intentions: an empirical study of the Italian context. Environment, Development and Sustainability: A Multidisciplinary Approach to the Theory and Practice of Sustainable Development, 22, 3519-3576.

AUDRETSCH, D. B. \& KEILBACH, M. 2004. Entrepreneurship capital and economic performance. Regional Studies, 38, 949-959.

BAILEY, D. \& KATZ, J. N. 2011. Implementing Panel Corrected Standard Errors in R: The pcse Package. Journal of Statistical Software, 42, 1-11.

BALAND, J.-M. \& FRANCOIS, P. 2000. Rent-seeking and resource booms. Journal of development Economics, 61, 527-542.

BARBIER, E. B. 2005. Natural Resource-Based Economic Development in History. World Economics, 6, 103-152.

BAUMOL, W. J. 1968. Entrepreneurship in Economic Theory. American Economic Review, 58, 64-71.

BAUMOL, W. J. 2004. ON ENTREPRENEURSHIP, GROWTH AND RENT-SEEKING: HENRY GEORGE UPDATED. American Economist, 48, 9-16.

BEHRENS, A., GILJUM, S., KOVANDA, J. \& NIZA, S. 2007. The material basis of the global economy: Worldwide patterns of natural resource extraction and their implications for sustainable resource use policies. Ecological Economics, 64, 444-453.

BEN-SALHA, O., DACHRAOUI, H. \& SEBRI, M. 2019. Natural resource rents and economic growth in the top resource-abundant countries: A PMG estimation. Resources Policy, Article in Press.

BISCHOFF, K. 2019. A study on the perceived strength of sustainable entrepreneurial ecosystems on the dimensions of stakeholder theory and culture. Small Business Economics: An Entrepreneurship Journal, 1.

BRETSCHGER, L. 2005. Economics of technological change and the natural environment: How effective are innovations as a remedy for resource scarcity? Ecological Economics, 54, 148-163.

BUENSTORF, G. 2016. Schumpeterian Incumbents and Industry Evolution. Journal of Evolutionary Economics, 26, 823-836.

CANH, N. P., KIM, S. \& THANH, S. D. 2020. Entrepreneurship and natural resource rent-seeking: The roles of institutional quality. Economics Bulletin, 40, 1159-1177.

CANH, N. P., THANH, S. D., SCHINCKUS, C., BENSEMANN, J. \& THANH, L. T. 2019. Global Emissions: A New Contribution from the Shadow Economy. International Journal of Energy Economics and Policy, 9, 320-337.

CANH, N. P. \& THONG, N. T. 2020. Nexus between financialisation and natural resources rents: Empirical evidence in a global sample. Resources Policy, 66, 101590.

CHAMBERS, D. \& MUNEMO, J. 2019. Regulations, institutional quality and entrepreneurship. Journal of Regulatory Economics, 55, 46-66.

CHELL, E. 2000. Towards researching the "opportunistic entrepreneur": A social constructionist approach and research agenda. European Journal of Work and Organizational Psychology, 9, 6380.

CHOWDHURY, F., AUDRETSCH, D. B. \& BELITSKI, M. 2019. Institutions and Entrepreneurship Quality. Entrepreneurship Theory and Practice, 43, 51-81. 
CLARK, P. K. 1987. The cyclical component of US economic activity. The Quarterly Journal of Economics, 102, 797-814.

CRESSY, R. 1992. The Theory of the Opportunistic Entrepreneur. Small Business Economics, 4, 267-271.

DANNEELS, E. 2012. Second-order competences and Schumpeterian rents. Strategic Entrepreneurship Journal, 6, 42-58.

DE HOYOS, R. E. \& SARAFIDIS, V. 2006. Testing for cross-sectional dependence in panel-data models. The stata journal, 6, 482-496.

DVOULETÝ, O. 2018. How to analyse determinants of entrepreneurship and self-employment at the country level? A methodological contribution. Journal of Business Venturing Insights, 9, 92-99.

ELBRA, A. D. 2013. The forgotten resource curse: South Africa's poor experience with mineral extraction. Resources Policy, 38, 549-557.

ESTAPÉ-DUBREUIL, G., ASHTA, A. \& HÉDOU, J.-P. 2016. Micro-equity for sustainable development: Selection, monitoring and exit strategies of micro-angels. Ecological Economics, 130, 117-129.

FUENTELSAZ, L., GONZÁLEZ, C. \& MAICAS, J. P. 2019. Formal institutions and opportunity entrepreneurship. The contingent role of informal institutions. BRQ Business Research Quarterly, 22, 5-24.

FUENTELSAZ, L., MAICAS, J. P. \& MONTERO, J. 2018. Entrepreneurs and innovation: The contingent role of institutional factors. International Small Business Journal, 36, 686-711.

GALINDO, M.-Á. \& MÉNDEZ, M. T. 2014. Entrepreneurship, economic growth, and innovation: Are feedback effects at work? Journal of Business Research, 67, 825-829.

HAAS, T. 2011. Improving natural resource management: ecological and political models, John Wiley and Sons Incorporated.

HAJZLER, C. 2014. Resource-based FDI and expropriation in developing economies. Journal of International Economics, 92, 124-146.

HAMILTON, J. D. 2018. Why you should never use the Hodrick-Prescott filter. Review of Economics and Statistics, 100, 831-843.

HODRICK, R. J. \& PRESCOTT, E. C. 1997. Postwar US business cycles: an empirical investigation. Journal of Money, credit, and Banking, 1-16.

JÖNSSON, K. 2005. Cross-sectional Dependency and Size Distortion in a Small-sample Homogeneous Panel Data Unit Root Test. Oxford Bulletin of Economics and Statistics, 67, 369-392.

LAFUENTE, E., SZERB, L. \& ACS, Z. J. 2018. The Entrepreneurship Paradox: More Entrepreneurs Are Not Always Good for the Economy - The Role of the Entrepreneurial Ecosystem on Economic Performance in Africa. Available at SSRN: https://ssrn.com/abstract=3307617 or http://dx.doi.org/10.2139/ssrn.3307617.

LIN, B.-Q. \& LIU, J.H. 2010. Estimating coal production peak and trends of coal imports in China. Energy Policy, 38, 512-519.

LUDEKE-FREUND, F. 2020. Sustainable entrepreneurship, innovation, and business models: Integrative framework and propositions for future research. Business Strategy and The Environment, 665.

MARQUES, A. C. \& FUINHAS, J. A. 2012. Is renewable energy effective in promoting growth? Energy Policy, 46, 434-442.

MCMULLEN, J. S., BAGBY, D. R. \& PALICH, L. E. 2008. Economic Freedom and the Motivation to Engage in Entrepreneurial Action. Entrepreneurship: Theory \& Practice, 32, 875-895.

MUDAKKAR, S. R., ZAMAN, K., KHAN, M. M. \& AHMAD, M. 2013. Energy for economic growth, industrialization, environment and natural resources: Living with just enough. Renewable and Sustainable Energy Reviews, 25, 580-595.

MUNASINGHE, M., JAYASINGHE, P., DERANIYAGALA, Y., MATLABA, V. J., SANTOS, J. F. D., MANESCHY, M. C. \& MOTA, J. A. 2019. Value-Supply Chain Analysis (VSCA) of crude palm oil production in 
Brazil, focusing on economic, environmental and social sustainability. Sustainable Production and Consumption, 17, 161-175.

MURPHY, K. M., SHLEIFER, A. \& VISHNY, R. W. 1993. Why is rent-seeking so costly to growth? American Economic Review, 83, 409-414.

NDIKUMANA, L. \& SARR, M. 2019. Capital flight, foreign direct investment and natural resources in Africa. Resources Policy, 63, 101427.

NGUYEN, B. 2019. Entrepreneurial Reinvestment: Local Governance, Ownership, and Financing Matter Evidence from Vietnam. Journal of Small Business Management, 57, 323-349.

NGUYEN, B., CANH, N. P. \& THANH, S. D. Institutions, Human Capital and Entrepreneurship Density. Journal of the Knowledge Economy, 1-24.

ORPHANIDES, A. \& NORDEN, S. V. 2002. The unreliability of output-gap estimates in real time. Review of economics and statistics, 84, 569-583.

PESARAN, M. H. 2004. General diagnostic tests for cross section dependence in panels.

PESARAN, M. H. 2006. Estimation and inference in large heterogeneous panels with a multifactor error structure. Econometrica, 74, 967-1012.

PHUC NGUYEN, C., SCHINCKUS, C. \& DINH SU, T. 2019. Economic integration and CO2 emissions: evidence from emerging economies. Climate and Development, 1-16.

POTTS, J., FOSTER, J. \& STRATON, A. 2010. An entrepreneurial model of economic and environmental coevolution. Ecological Economics, 70, 375-383.

PRIEGER, J. E., BAMPOKY, C., BLANCO, L. R. \& LIU, A. 2016. Economic Growth and the Optimal Level of Entrepreneurship. World Development, 82, 95-109.

RAMOS-RODRÍGUEZ, A. R., MEDINA-GARRIDO, J. A. \& RUIZ-NAVARRO, J. 2012. Determinants of Hotels and Restaurants entrepreneurship: A study using GEM data. International Journal of Hospitality Management, 31, 579-587.

REPORT, W. T. 2010. Trade in Natural Resources. Geneva.

ROBERTSON, D. \& SYMONS, J. 2000. Factor residuals in SUR regressions: estimating panels allowing for cross sectional correlation, Centre for Economic Performance, London School of Economics and Political ....

ROBINSON, J. A. 1994. Investment and political instability, Department of Economics, University of Melbourne.

SASU, C. \& SASU, L. 2015. Demographic Determinant of the Entrepreneurship Intentions. The Case of Romania. Procedia Economics and Finance, 20, 580-585.

SAUTET, F. 2013. Local and systemic entrepreneurship: solving the puzzle of entrepreneurship and economic development. Entrepreneurship: Theory and Practice, 387.

SCHUMPETER, J. A. 1965. The theory of economic development an inquiry into profits, capital, credit, interest, and the business cycle, New York, Oxford Univ. Press.

SHEN, L., CHENG, S., GUNSON, A. J. \& WAN, H. 2005. Urbanization, sustainability and the utilization of energy and mineral resources in China. Cities, 22, 287-302.

STEPHAN, U., UHLANER, L. M. \& STRIDE, C. 2015. Institutions and social entrepreneurship: the role of institutional voids, institutional support, and institutional configurations. Journal of International Business Studies, 46, 308-331.

STERN, D. I. 2004. The rise and fall of the environmental Kuznets curve. World development, 32, 14191439.

THAI, M. T. T. \& TURKINA, E. 2014. Macro-level determinants of formal entrepreneurship versus informal entrepreneurship. Journal of Business Venturing, 29, 490-510.

TIBA, S., RIJNSOEVER, F. J. \& HEKKERT, M. P. 2019. Firms with benefits: A systematic review of responsible entrepreneurship and corporate social responsibility literature. Corporate Social Responsibility and Environmental Management, 265. 
TORVIK, R. 2002. Natural resources, rent seeking and welfare. Journal of development Economics, 67, 455-470.

TOWLER, B., FIROUZI, M., UNDERSCHULTZ, J., RIFKIN, W., GARNETT, A., SCHULTZ, H., ESTERLE, J., TYSON, S. \& WITT, K. 2016. An overview of the coal seam gas developments in Queensland. Journal of Natural Gas Science and Engineering, 31, 249-271.

TULLOCK, G. 1967. THE WELFARE COSTS OF TARIFFS, MONOPOLIES, AND THEFT. Economic Inquiry, 5, 224-232.

VAN LUNENBURG, M., GEUIJEN, K. \& MEIJER, A. 2020. How and Why Do Social and Sustainable Initiatives Scale? A Systematic Review of the Literature on Social Entrepreneurship and Grassroots Innovation. International Journal of Voluntary and Nonprofit Organizations, 1.

VOLKMANN, C., FICHTER, K., KLOFSTEN, M. \& AUDRETSCH, D. B. 2019. Sustainable entrepreneurial ecosystems: an emerging field of research. Small Business Economics: An Entrepreneurship Journal, 1.

WENNEKERS, S. \& THURIK, R. 1999. Linking Entrepreneurship and Economic Growth. Small Business Economics, 13, 27. 
Table 1. Estimations of excessive entrepreneurship

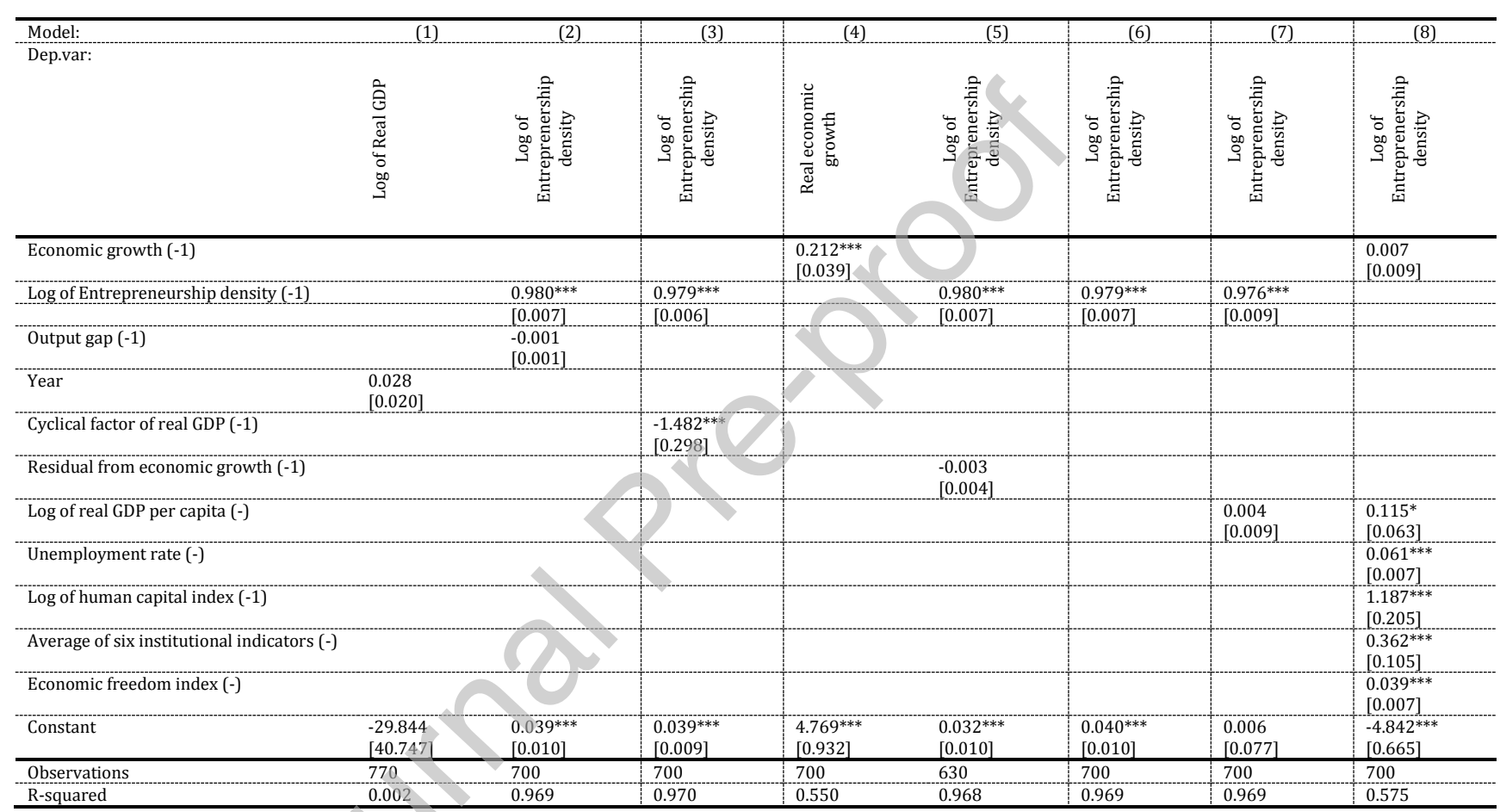

Note: standard errors are in []; * ,**,*** are significant levels at $10 \%, 5 \%$, and $1 \%$, respectively. 
Table 2. Variables, definitions, measurements, sources, data description and CD tests

\begin{tabular}{|c|c|c|c|c|c|c|c|c|c|}
\hline Variable & Definitions & Measurements & Sources & Obs & Mean & SD. & Min & Max & CD-test \\
\hline NRR & Natural resources rents & Total natural resources rents (\% of GDP) & WDIs & 770 & 3.47 & 5.10 & 0.00 & 32.55 & $38.50^{* * *}$ \\
\hline CoalR & Coal rents & Coal rents (\% of GDP) & WDIs & 770 & 0.19 & 0.60 & 0.00 & 7.85 & $30.44^{* * *}$ \\
\hline MineR & Mineral rents & Mineral rents (\% of GDP) & WDIs & 770 & 1.41 & 3.12 & 0.00 & 20.92 & $18.96^{* * *}$ \\
\hline GasR & Natural gas rents & Natural gas rents (\% of GDP) & WDIs & 770 & 0.32 & 0.76 & 0.00 & 4.89 & $22.84 * * *$ \\
\hline ForestR & Forest rents & Forest rents (\% of GDP) & WDIs & 770 & 0.50 & 0.97 & 0.00 & 8.58 & $10.41^{* * *}$ \\
\hline Income & Income level & Log of GDP per capita (constant 2010 US $\$$ ) & WDIs & 770 & 9.20 & 1.32 & 6.13 & 11.63 & $75.12^{* * *}$ \\
\hline Cap & Capital formation & Gross capital formation (\% of GDP) & WDIs & 766 & 24.43 & 5.86 & 12.32 & 44.31 & $31.01^{* * *}$ \\
\hline Urban & Urbanization & Urban population ( $\%$ of total) & WDIs & 770 & 65.04 & 18.80 & 15.46 & 100.00 & $82.15^{* * *}$ \\
\hline Trade & Trade openness & Trade (\% of GDP) & WDIs & 770 & 95.64 & 59.71 & 20.72 & 441.60 & $29.15^{* * * *}$ \\
\hline FDI & FDI inflows & $\begin{array}{l}\text { Foreign direct investment, net inflows (\% } \\
\text { of GDP) }\end{array}$ & WDIs & 770 & 5.98 & 14.92 & -58.32 & 252.31 & $23.46^{* * *}$ \\
\hline \multicolumn{10}{|c|}{ Data description for the estimations of excessive entrepreneurship } \\
\hline \multicolumn{3}{|c|}{ Residual from model (1) } & 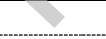 & 770 & \multicolumn{2}{|c|}{0.000} & 1.777 & -3.343 & 3.392 \\
\hline \multicolumn{3}{|c|}{ Output gap } & & 770 & \multicolumn{2}{|c|}{-0.488} & 7.045 & -15.123 & 11.751 \\
\hline \multicolumn{3}{|c|}{ Residual from model (2) } & & 700 & \multicolumn{2}{|c|}{0.000} & 0.227 & -2.174 & 1.369 \\
\hline \multicolumn{4}{|c|}{ Cyclical factor from HP filter for log of real GDP } & 770 & \multicolumn{2}{|c|}{0.000} & 0.029 & -0.125 & 0.139 \\
\hline \multicolumn{4}{|c|}{ Residual from model (3) } & 700 & \multicolumn{2}{|c|}{0.000} & 0.224 & -2.191 & 1.385 \\
\hline \multicolumn{4}{|c|}{ Residual from model (4) } & 700 & \multicolumn{2}{|c|}{0.000} & 2.529 & -12.856 & 19.758 \\
\hline \multicolumn{4}{|c|}{ Residual from model (5) } & 630 & \multicolumn{2}{|c|}{0.000} & 0.230 & -2.158 & 1.396 \\
\hline \multicolumn{4}{|c|}{ Residual from model (6) } & 700 & \multicolumn{2}{|c|}{0.000} & 0.228 & -2.161 & 1.383 \\
\hline \multicolumn{4}{|c|}{ Residual from model (7) } & 700 & \multicolumn{2}{|c|}{0.000} & 0.228 & -2.154 & 1.388 \\
\hline \multicolumn{4}{|c|}{ Residual from model (8) } & 700 & \multicolumn{2}{|c|}{0.000} & 0.848 & -2.206 & 2.637 \\
\hline
\end{tabular}

Note: WDIs is World Development Indicators database, World Bank (version Apr/2019); Fred is economic database of Federal reserve system of St Lousis (US); in CD test: Under the null

hypothesis of cross-section independence, $\mathrm{CD} \sim \mathrm{N}(0,1)$, p-values close to zero indicate data are correlated across panel groups. 
Table 3. Excessive entrepreneurship and natural resources rents

\begin{tabular}{|c|c|c|c|c|c|c|c|c|c|c|}
\hline Dep. var: $\boldsymbol{N R \boldsymbol { R }}$ & (1) & (2) & (3) & (4) & (5) & (6) & $(7)$ & $(8)$ & (9) & $(10)$ \\
\hline Income & $\begin{array}{l}2.680^{* * *} \\
{[0.698]}\end{array}$ & $\begin{array}{l}3.461^{* * *} \\
{[0.588]}\end{array}$ & $\begin{array}{l}0.993^{*} \\
{[0.547]}\end{array}$ & $\begin{array}{l}-0.014 \\
{[0.515]}\end{array}$ & $\begin{array}{l}0.193 \\
{[0.467]}\end{array}$ & $\begin{array}{l}0.200 \\
{[0.451]}\end{array}$ & $\begin{array}{l}0.167 \\
{[0.476]}\end{array}$ & $\begin{array}{l}0.153 \\
{[0.469]}\end{array}$ & $\begin{array}{l}0.129 \\
{[0.463]}\end{array}$ & $\begin{array}{l}-0.544 \\
{[0.498]}\end{array}$ \\
\hline Income ${ }^{\wedge} 2$ & $\begin{array}{l}-0.213^{* * *} \\
{[0.039]}\end{array}$ & $\begin{array}{l}-0.250^{* * *} \\
{[0.034]}\end{array}$ & $\begin{array}{l}-0.145^{* * *} \\
{[0.032]}\end{array}$ & $\begin{array}{l}-0.078^{* * *} \\
{[0.030]}\end{array}$ & $\begin{array}{l}-0.089^{* * *} \\
{[0.028]}\end{array}$ & $\begin{array}{l}-0.088^{* * *} \\
{[0.027]}\end{array}$ & $\begin{array}{l}0.087^{* * *} \\
{[0.028]}\end{array}$ & $\begin{array}{l}-0.087^{* * *} \\
{[0.028]}\end{array}$ & $\begin{array}{l}-0.085^{* * *} \\
{[0.028]}\end{array}$ & $\begin{array}{l}-0.049^{*} \\
{[0.029]}\end{array}$ \\
\hline DUM1 & $\begin{array}{l}\mathbf{0 . 7 6 0} \\
{[0.363]}\end{array}$ & $\begin{array}{l}\mathbf{0 . 6 8 7} * * \\
{[0.334]}\end{array}$ & $\begin{array}{l}0.670^{*} \\
{[0.343]}\end{array}$ & $\begin{array}{l}\mathbf{0 . 7 2 4} * * \\
{[0.361]}\end{array}$ & $\begin{array}{l}\mathbf{0 . 7 1 0}^{* *} \\
{[0.356]}\end{array}$ & & & & & \\
\hline DUM2 & & & & & & $\begin{array}{l}\mathbf{0 . 7 7 0}^{*} \\
{[0.408]}\end{array}$ & & & & \\
\hline DUM3 & & & & & & & $\begin{array}{l}\mathbf{0 . 7 3 0} \\
{[0.365]}\end{array}$ & & & \\
\hline DUM4 & & & & & & & & $\begin{array}{l}\mathbf{0 . 6 1 7} \\
{[0.338]}\end{array}$ & & \\
\hline DUM5 & & & & & & 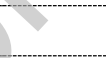 & & & $\begin{array}{l}\text { 0.605* } \\
{[0.330]}\end{array}$ & \\
\hline DUM6 & & & & & & & & & & $\begin{array}{l}\mathbf{2 . 5 3 8}^{* * *} \\
{[0.342]}\end{array}$ \\
\hline Cap & & $\begin{array}{l}0.008 \\
{[0.029]}\end{array}$ & $\begin{array}{l}0.021 \\
{[0.026]}\end{array}$ & $\begin{array}{l}0.037 \\
{[0.026]}\end{array}$ & $\begin{array}{l}0.038 \\
{[0.026]}\end{array}$ & $\begin{array}{l}0.034 \\
{[0.026]}\end{array}$ & $\begin{array}{l}0.036 \\
{[0.027]}\end{array}$ & $\begin{array}{l}0.039 \\
{[0.026]}\end{array}$ & $\begin{array}{l}0.039 \\
{[0.026]}\end{array}$ & $\begin{array}{l}0.033 \\
{[0.027]}\end{array}$ \\
\hline Urban & & & $\begin{array}{l}0.053^{* * * *} \\
{[0.003]}\end{array}$ & $\begin{array}{l}0.055^{* * * *} \\
{[0.004]}\end{array}$ & $\begin{array}{l}0.054^{* * *} \\
{[0.004]}\end{array}$ & $\begin{array}{l}0.052^{* * *} \\
{[0.004]}\end{array}$ & $\begin{array}{l}0.054^{* * *} \\
{[0.004]}\end{array}$ & $\begin{array}{l}0.054^{* * *} \\
{[0.004]}\end{array}$ & $\begin{array}{l}0.054^{* * *} \\
{[0.004]}\end{array}$ & $\begin{array}{l}0.059^{* * *} \\
{[0.003]}\end{array}$ \\
\hline Trade & & & & $\begin{array}{l}-0.014^{* * *} \\
{[0.002]}\end{array}$ & $\begin{array}{l}-0.015^{* * *} \\
{[0.002]}\end{array}$ & $\begin{array}{l}-0.015^{* * *} \\
{[0.002]}\end{array}$ & $\begin{array}{l}-0.015^{* * *} \\
{[0.002]}\end{array}$ & $\begin{array}{l}-0.015^{* * *} \\
{[0.002]}\end{array}$ & $\begin{array}{l}-0.015^{* * *} \\
{[0.002]}\end{array}$ & $\begin{array}{l}-0.015^{* * *} \\
{[0.002]}\end{array}$ \\
\hline FDI & & & & & $\begin{array}{l}0.014^{* *} \\
{[0.007]}\end{array}$ & $\begin{array}{l}0.014^{* *} \\
{[0.007]}\end{array}$ & $\begin{array}{l}0.014^{* *} \\
{[0.007]}\end{array}$ & $\begin{array}{l}0.015^{* *} \\
{[0.007]}\end{array}$ & $\begin{array}{l}0.014^{* *} \\
{[0.007]}\end{array}$ & $\begin{array}{l}0.010^{*} \\
{[0.006]}\end{array}$ \\
\hline Cons. & $\begin{array}{l}-3.268 \\
{[2.976]}\end{array}$ & $\begin{array}{l}-7.431^{* * * *} \\
{[2.244]}\end{array}$ & $\begin{array}{l}2.405 \\
{[2.163]}\end{array}$ & $\begin{array}{l}6.619^{* * *} \\
{[1.934]}\end{array}$ & $\begin{array}{l}5.787^{* * * *} \\
{[1.746]}\end{array}$ & $\begin{array}{l}5.810^{* * *} \\
{[1.675]}\end{array}$ & $\begin{array}{l}5.872^{* * *} \\
{[1.813]}\end{array}$ & $\begin{array}{l}5.986^{* * * *} \\
{[1.756]}\end{array}$ & $\begin{array}{l}6.079^{* * *} \\
{[1.722]}\end{array}$ & $\begin{array}{l}7.964^{* * *} \\
{[1.720]}\end{array}$ \\
\hline Observations & 770 & 766 & 766 & 766 & 766 & 766 & 766 & 766 & 766 & 766 \\
\hline $\mathrm{R}$-squared & 0.098 & 0.091 & 0.106 & 0.128 & 0.130 & 0.131 & 0.130 & 0.129 & 0.129 & 0.189 \\
\hline No. of countries & 70 & 70 & 70 & 70 & 70 & 70 & 70 & 70 & 70 & 70 \\
\hline
\end{tabular}


Table 4. Excessive entrepreneurship and natural resources rents: high income economies

\begin{tabular}{|c|c|c|c|c|c|c|c|c|c|c|}
\hline Dep. var: $\boldsymbol{N R \boldsymbol { R }}$ & (1) & $(2)$ & (3) & $(4)$ & $(5)$ & $(6)$ & $(7)$ & $(8)$ & (9) & $(10)$ \\
\hline Income & $\begin{array}{l}-35.193^{* * *} \\
{[1.883]}\end{array}$ & $\begin{array}{l}-34.756^{* * *} \\
{[2.051]}\end{array}$ & $\begin{array}{l}-34.401^{* * *} \\
{[1.805]}\end{array}$ & $\begin{array}{l}-52.286^{* * *} \\
{[2.718]}\end{array}$ & $\begin{array}{l}-52.293^{* * *} \\
{[2.711]}\end{array}$ & $\begin{array}{l}-50.835^{* * *} \\
{[2.544]}\end{array}$ & $\begin{array}{l}-51.422^{* * *} \\
{[2.360]}\end{array}$ & $\begin{array}{l}-51.434^{* * *} \\
{[2.534]}\end{array}$ & $\begin{array}{l}-51.678^{* * *} \\
{[2.308]}\end{array}$ & $\begin{array}{l}-51.603^{\text {**** }} \\
{[2.245]}\end{array}$ \\
\hline Income $^{\wedge} 2$ & $\begin{array}{l}1.702^{* * *} \\
{[0.092]}\end{array}$ & $\begin{array}{l}1.681^{* * *} \\
{[0.099]}\end{array}$ & $\begin{array}{l}1.639 * * \\
{[0.088]}\end{array}$ & $\begin{array}{l}2.526^{* * *} \\
{[0.134]}\end{array}$ & $\begin{array}{l}2.527^{* * *} \\
{[0.133]}\end{array}$ & $\begin{array}{l}2.457^{* * *} \\
{[0.125]}\end{array}$ & $\begin{array}{l}2.484^{* * *} \\
{[0.116]}\end{array}$ & $\begin{array}{l}2.487^{* * *} \\
{[0.125]}\end{array}$ & $\begin{array}{l}2.497^{* * *} \\
{[0.114]}\end{array}$ & $\begin{array}{l}2.490^{* * *} \\
{[0.112]}\end{array}$ \\
\hline DUM2 & & & & & & $\begin{array}{c}\mathbf{0 . 8 0 4} * * \\
{[0.342]}\end{array}$ & & & & \\
\hline DUM3 & & & & & & & $\begin{array}{l}\mathbf{0 . 8 2 1 * *} \\
{[0.361]}\end{array}$ & & & \\
\hline DUM5 & & & & & & $\theta$ & & & $\begin{array}{l}\mathbf{0 . 7 1 3} \\
{[0.374]}\end{array}$ & \\
\hline DUM6 & & & & & & & & & & $\begin{array}{l}0.922^{* *} \\
{[0.371]}\end{array}$ \\
\hline Cap & & $\begin{array}{l}0.008 \\
{[0.018]}\end{array}$ & $\begin{array}{l}0.009 \\
{[0.010]}\end{array}$ & $\begin{array}{l}0.026^{* *} \\
{[0.013]}\end{array}$ & $\begin{array}{l}0.026^{* *} \\
{[0.013]}\end{array}$ & $\begin{array}{l}0.019 \\
{[0.012]}\end{array}$ & $\begin{array}{l}0.016 \\
{[0.011]}\end{array}$ & $\begin{array}{l}0.020^{*} \\
{[0.011]}\end{array}$ & $\begin{array}{l}0.024^{* *} \\
{[0.012]}\end{array}$ & $\begin{array}{l}0.035^{* *} \\
{[0.017]}\end{array}$ \\
\hline Urban & & & $\begin{array}{l}0.063^{* * *} \\
{[0.003]}\end{array}$ & $\begin{array}{l}0.067^{* * *} \\
{[0.005}\end{array}$ & $\begin{array}{l}0.067^{* * *} \\
{[0.005]}\end{array}$ & $\begin{array}{l}0.067^{* * *} \\
{[0.006]}\end{array}$ & $\begin{array}{l}0.068^{* * *} \\
{[0.005]}\end{array}$ & $\begin{array}{l}0.067^{* * *} \\
{[0.005]}\end{array}$ & $\begin{array}{l}0.068^{* * *} \\
{[0.005]}\end{array}$ & $\begin{array}{l}0.075^{* * * *} \\
{[0.006]}\end{array}$ \\
\hline Trade & & & & $\begin{array}{l}-0.017^{* * *} \\
{[0.001]}\end{array}$ & $\begin{array}{l}-0.017^{* * *} \\
{[0.001]}\end{array}$ & $\begin{array}{l}-0.017^{* * *} \\
{[0.001]}\end{array}$ & $\begin{array}{l}-0.017^{* * *} \\
{[0.001]}\end{array}$ & $\begin{array}{l}-0.017^{* * *} \\
{[0.001]}\end{array}$ & $\begin{array}{l}-0.017^{* * *} \\
{[0.001]}\end{array}$ & $\begin{array}{l}-0.016^{* * *} \\
{[0.001]}\end{array}$ \\
\hline Cons. & $\begin{array}{l}182.138^{* * *} \\
{[9.660]}\end{array}$ & $\begin{array}{l}179.652^{\text {*** }} \\
{[10.821]}\end{array}$ & $\begin{array}{l}175.788^{* * *} \\
{[9.201]}\end{array}$ & $\begin{array}{l}266.743^{* * *} \\
{[13.682]}\end{array}$ & $\begin{array}{l}266.777^{* * *} \\
{[13.624]}\end{array}$ & $\begin{array}{l}259.414^{* * *} \\
{[12.830]}\end{array}$ & $\begin{array}{l}262.431^{* * *} \\
{[11.885]}\end{array}$ & $\begin{array}{l}262.297^{* * *} \\
{[12.735]}\end{array}$ & $\begin{array}{l}263.730^{* * *} \\
{[11.544]}\end{array}$ & $\begin{array}{l}262.639^{* * *} \\
{[10.757]}\end{array}$ \\
\hline Observations & 374 & 374 & 374 & 374 & 374 & 374 & 374 & 374 & 374 & 374 \\
\hline R-squared & 0.072 & 0.072 & 0.119 & 0.237 & 0.237 & 0.232 & 0.232 & 0.237 & 0.230 & 0.237 \\
\hline No. of countries & 34 & 34 & 34 & 34 & 34 & 34 & 34 & 34 & 34 & 34 \\
\hline
\end{tabular}


Table 5. Excessive entrepreneurship and natural resources rents in low and middle income economies (LMES)

\begin{tabular}{|c|c|c|c|c|c|c|c|c|c|c|}
\hline Dep. var: $\boldsymbol{N R \boldsymbol { R }}$ & (1) & $(2)$ & (3) & $(4)$ & (5) & $(6)$ & $(7)$ & $(8)$ & (9) & $(10)$ \\
\hline Income & $\begin{array}{l}-4.994^{* * * *} \\
{[1.506]}\end{array}$ & $\begin{array}{l}-5.405^{* * *} \\
{[1.562]}\end{array}$ & $\begin{array}{l}-7.521^{* * *} \\
{[2.039]}\end{array}$ & $\begin{array}{l}-6.236^{* * *} \\
{[2.096]}\end{array}$ & $\begin{array}{l}-6.073^{* * *} \\
{[1.834]}\end{array}$ & $\begin{array}{l}-7.234^{* * *} \\
{[1.618]}\end{array}$ & $\begin{array}{l}-7.078^{* * *} \\
{[1.631]}\end{array}$ & $\begin{array}{l}-7.081^{* * *} \\
{[1.631]}\end{array}$ & $\begin{array}{l}-6.599^{* * * *} \\
{[1.739]}\end{array}$ & $\begin{array}{l}-1.626 \\
{[2.211]}\end{array}$ \\
\hline Income ${ }^{\wedge} 2$ & $\begin{array}{l}0.335^{* * *} \\
{[0.096]}\end{array}$ & $\begin{array}{l}0.374^{* * *} \\
{[0.098]}\end{array}$ & $\begin{array}{l}0.485^{* * *} \\
{[0.121]}\end{array}$ & $\begin{array}{l}0.408^{* * *} \\
{[0.125]}\end{array}$ & $\begin{array}{l}0.408^{* * *} \\
{[0.109]}\end{array}$ & $\begin{array}{l}0.482^{* * *} \\
{[0.096]}\end{array}$ & $\begin{array}{l}0.473^{* * *} \\
{[0.096]}\end{array}$ & $\begin{array}{l}0.472^{* * *} \\
{[0.097]}\end{array}$ & $\begin{array}{l}0.440^{* * *} \\
{[0.103]}\end{array}$ & $\begin{array}{l}0.105 \\
{[0.134]}\end{array}$ \\
\hline DUM1 & $\begin{array}{l}1.341^{*} \\
{[0.705]}\end{array}$ & $\begin{array}{l}1.209^{*} \\
{[0.645]}\end{array}$ & $\begin{array}{l}1.203^{*} \\
{[0.640]}\end{array}$ & $\begin{array}{l}1.206^{*} \\
{[0.636]}\end{array}$ & $\begin{array}{l}1.075^{*} \\
{[0.627]}\end{array}$ & & & & & \\
\hline DUM2 & & & & & & $\begin{array}{l}\mathbf{0 . 4 8 4} \\
{[0.689]}\end{array}$ & & & & \\
\hline DUM3 & & & & & & & $\begin{array}{l}\mathbf{0 . 4 7 5} \\
{[0.706]}\end{array}$ & & & \\
\hline DUM5 & & & & & & 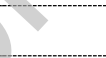 & & & $\begin{array}{l}\mathbf{0 . 8 5 4} \\
{[0.567]}\end{array}$ & \\
\hline DUM6 & & & & & & & & & & $\begin{array}{l}\mathbf{3 . 7 3 9 * * *} \\
{[0.386]}\end{array}$ \\
\hline Cap & & $\begin{array}{l}0.000 \\
{[0.037]}\end{array}$ & $\begin{array}{l}0.010 \\
{[0.037]}\end{array}$ & $\begin{array}{l}0.014 \\
{[0.038]}\end{array}$ & $\begin{array}{l}-0.028 \\
{[0.038]}\end{array}$ & $\begin{array}{l}-0.025 \\
{[0.037]}\end{array}$ & $\begin{array}{l}-0.025 \\
{[0.037]}\end{array}$ & $\begin{array}{l}-0.024 \\
{[0.037]}\end{array}$ & $\begin{array}{l}-0.026 \\
{[0.037]}\end{array}$ & $\begin{array}{l}-0.058 \\
{[0.041]}\end{array}$ \\
\hline Urban & & & $\begin{array}{l}0.023^{* * *} \\
{[0.007]}\end{array}$ & $\begin{array}{l}0.021^{* * *} \\
{[0.007]}\end{array}$ & $\begin{array}{l}0.005 \\
{[0.009]}\end{array}$ & $\begin{array}{l}0.006 \\
{[0.007]}\end{array}$ & $\begin{array}{l}0.006 \\
{[0.007]}\end{array}$ & $\begin{array}{l}0.006 \\
{[0.007]}\end{array}$ & $\begin{array}{l}0.007 \\
{[0.008]}\end{array}$ & $\begin{array}{l}0.030^{* * *} \\
{[0.007]}\end{array}$ \\
\hline Trade & & & & $\begin{array}{l}-0.008^{*} \\
{[0.004]}\end{array}$ & $\begin{array}{l}-0.020^{* * *} \\
{[0.005]}\end{array}$ & $\begin{array}{l}-0.020^{* * *} \\
{[0.005]}\end{array}$ & $\begin{array}{l}-0.020^{* * *} \\
{[0.005]}\end{array}$ & $\begin{array}{l}-0.020^{* * *} \\
{[0.005]}\end{array}$ & $\begin{array}{l}-0.020^{* * *} \\
{[0.005]}\end{array}$ & $\begin{array}{l}-0.029^{* * *} \\
{[0.006]}\end{array}$ \\
\hline Cons. & $\begin{array}{l}22.768^{* * *} \\
{[6.003]}\end{array}$ & $\begin{array}{l}23.407^{* * * *} \\
{[6.675]}\end{array}$ & $\begin{array}{l}31.709^{* * *} \\
{[8.470]}\end{array}$ & $\begin{array}{l}26.993^{* * *} \\
{[8.655]}\end{array}$ & $\begin{array}{l}27.314^{* * * *} \\
{[7.597]}\end{array}$ & $\begin{array}{l}31.986^{* * *} \\
{[6.776]}\end{array}$ & $\begin{array}{l}31.339^{* * * *} \\
{[6.836]}\end{array}$ & $\begin{array}{l}31.465^{* * *} \\
{[6.792]}\end{array}$ & $\begin{array}{l}29.467^{* * *} \\
{[7.230]}\end{array}$ & $\begin{array}{l}10.158 \\
{[8.818]}\end{array}$ \\
\hline Observations & 396 & 392 & 392 & 392 & 392 & 392 & 392 & 392 & 392 & 392 \\
\hline $\mathrm{R}$-squared & 0.020 & 0.024 & 0.026 & 0.028 & 0.054 & 0.046 & 0.046 & 0.046 & 0.050 & 0.145 \\
\hline No. of countries & 36 & 36 & 36 & 36 & 36 & 36 & 36 & 36 & 36 & 36 \\
\hline
\end{tabular}




\section{Appendix}

Table A1. List of countries

\begin{tabular}{|c|c|c|c|c|}
\hline \multicolumn{5}{|c|}{34 High income economies (HIEs) } \\
\hline Australia & Denmark & Israel & New Zealand & Slovenia \\
\hline Austria & Estonia & Italy & Norway & Spain \\
\hline Belgium & Finland & Korea, Rep. & Panama & Sweden \\
\hline Chile & France & Latvia & Poland & Switzerland \\
\hline Croatia & Germany & Lithuania & Portugal & United Kingdom \\
\hline Cyprus & Hungary & Luxembourg & Singapore & Uruguay \\
\hline Czech Republic & Ireland & Netherlands & Slovak Republic & \\
\hline \multicolumn{5}{|c|}{36 Low and middle income economies (LMEs) } \\
\hline Albania & India & Mauritius & Pakistan & Senegal \\
\hline Armenia & Indonesia & Mexico & Paraguay & South Africa \\
\hline Bolivia & Jamaica & Moldova & Peru & Tajikistan \\
\hline Botswana & Jordan & Morocco & Philippines & Thailand \\
\hline Brazil & Kazakhstan & Namibia & Romania & Turkey \\
\hline Costa Rica & Kyrgyz Republic & Nepal & Russian Federation & Ukraine \\
\hline Dominican Republic & Malaysia & Nigeria & Rwanda & Zambia \\
\hline \multicolumn{5}{|l|}{ El Salvador } \\
\hline \multicolumn{5}{|c|}{ Mean (Standard deviation) for subsamples } \\
\hline Variable & \multicolumn{2}{|c|}{ High income economies } & Low and middle-inco & conomies \\
\hline NRR & 1.47 & $(3.36)$ & 5.35 & $(5.70)$ \\
\hline CoalR & 0.08 & $(0.29)$ & 0.29 & $(0.77)$ \\
\hline MineR & 0.70 & $(2.88)$ & 2.09 & (3.19) \\
\hline GasR & 0.16 & $(0.46)$ & 0.48 & $(0.94)$ \\
\hline ForestR & 0.20 & $(0.31)$ & 0.77 & $(1.26)$ \\
\hline Income & 10.31 & $(0.64)$ & 8.16 & $(0.87)$ \\
\hline Cap & 23.52 & $(5.26)$ & 25.30 & $(6.26)$ \\
\hline Urban & 75.82 & (12.81) & 54.85 & $(17.87)$ \\
\hline Trade & 3 & $(73.7)$ & 76.21 & $(32.08)$ \\
\hline FDI & 8.26 & $(20.97)$ & 3.83 & $(2.98)$ \\
\hline EnDen & 1.42 & $(0.88)$ & -0.03 & $(1.26)$ \\
\hline
\end{tabular}


Table A2. Excessive entrepreneurship and coal rents, mineral rents

\begin{tabular}{|c|c|c|c|c|c|c|c|c|c|c|c|c|}
\hline Model: & (1) & (2) & (3) & (4) & (5) & (6) & (7) & (8) & (9) & $(10)$ & (11) & $(12)$ \\
\hline Dep. Var: & \multicolumn{6}{|c|}{ CoalR } & \multicolumn{6}{|c|}{ MineR } \\
\hline Income & $\begin{array}{l}0.646^{* * *} \\
{[0.063]}\end{array}$ & $\begin{array}{l}0.647^{* * *} \\
{[0.063]}\end{array}$ & $\begin{array}{l}0.646^{* * *} \\
{[0.064]}\end{array}$ & $\begin{array}{l}0.646^{* * *} \\
{[0.064]}\end{array}$ & $\begin{array}{l}0.647^{* * *} \\
{[0.063]}\end{array}$ & $\begin{array}{l}0.626^{* * *} \\
{[0.057]}\end{array}$ & $\begin{array}{l}-1.009^{* * *} \\
{[0.351]}\end{array}$ & $\begin{array}{l}-1.003^{* * *} \\
{[0.343]}\end{array}$ & $\begin{array}{l}-1.032^{* * *} \\
{[0.361]}\end{array}$ & $\begin{array}{l}-1.034^{* * *} \\
{[0.362]}\end{array}$ & $\begin{array}{l}-1.054^{* * *} \\
{[0.358]}\end{array}$ & $\begin{array}{l}-1.267^{* * * *} \\
{[0.382]}\end{array}$ \\
\hline Income ${ }^{\wedge} 2$ & $\begin{array}{l}-0.035^{* * *} \\
{[0.004]}\end{array}$ & $\begin{array}{l}-0.035^{* * *} \\
{[0.004]}\end{array}$ & $\begin{array}{l}-0.035^{* * *} \\
{[0.004]}\end{array}$ & $\begin{array}{l}-0.035^{* * *} \\
{[0.004]}\end{array}$ & $\begin{array}{l}-0.035^{* * *} \\
{[0.004]}\end{array}$ & $\begin{array}{l}-0.034^{* * *} \\
{[0.003]}\end{array}$ & $\begin{array}{l}-0.002 \\
{[0.017]}\end{array}$ & $\begin{array}{l}-0.001 \\
{[0.017]}\end{array}$ & $\begin{array}{l}-0.001 \\
{[0.018]}\end{array}$ & $\begin{array}{l}-0.001 \\
{[0.018]}\end{array}$ & $\begin{array}{l}0.001 \\
{[0.018]}\end{array}$ & $\begin{array}{l}0.012 \\
{[0.019]}\end{array}$ \\
\hline DUM1 & $\begin{array}{l}-\mathbf{0 . 0 1 1} \\
{[0.036]}\end{array}$ & & & & & & $\begin{array}{l}\mathbf{0 . 5 2 3}^{* * *} \\
{[0.150]}\end{array}$ & & & & & \\
\hline DUM2 & & $\begin{array}{l}-\mathbf{0 . 0 0 8} \\
{[0.041]}\end{array}$ & & & & & & $\begin{array}{l}0.578^{* * *} \\
{[0.167]}\end{array}$ & & & & \\
\hline DUM3 & & & $\begin{array}{l}-\mathbf{0 . 0 2 5} \\
{[0.039]}\end{array}$ & & & & & & $\begin{array}{l}\mathbf{0 . 4 8 7 * * *} \\
{[0.153]}\end{array}$ & & & \\
\hline DUM4 & & & & $\begin{array}{l}-0.019 \\
{[0.033]}\end{array}$ & & & & & & $\begin{array}{l}\mathbf{0 . 5 2 5}^{* * *} \\
{[0.152]}\end{array}$ & & \\
\hline DUM5 & & & & & $\begin{array}{l}-0.019 \\
{[0.035]}\end{array}$ & & & & & & $\begin{array}{l}\mathbf{0 . 5 1 7}^{* * *} \\
{[0.154]}\end{array}$ & \\
\hline DUM6 & & & & & & $\begin{array}{l}\mathbf{0 . 0 8 3} * * * \\
{[0.018]}\end{array}$ & r & & & & & $\begin{array}{l}\mathbf{0 . 7 6 9 * * *} \\
{[0.185]}\end{array}$ \\
\hline Cap & $\begin{array}{l}0.012^{* * *} \\
{[0.002]}\end{array}$ & $\begin{array}{l}0.012^{* * *} \\
{[0.002]}\end{array}$ & $\begin{array}{l}0.012^{* * *} \\
{[0.002]}\end{array}$ & $\begin{array}{l}0.012^{* * *} \\
{[0.002]}\end{array}$ & $\begin{array}{l}0.012^{* * * *} \\
{[0.002]}\end{array}$ & $\begin{array}{l}0.011^{* * *} \\
{[0.002]}\end{array}$ & $\begin{array}{l}0.074^{* * * *} \\
{[0.016]}\end{array}$ & $\begin{array}{l}0.071^{* * *} \\
{[0.016]}\end{array}$ & $\begin{array}{l}0.073^{* * *} \\
{[0.016]}\end{array}$ & $\begin{array}{l}0.074^{* * *} \\
{[0.016]}\end{array}$ & $\begin{array}{l}0.074^{* * *} \\
{[0.016]}\end{array}$ & $\begin{array}{l}0.075^{* * *} \\
{[0.016]}\end{array}$ \\
\hline Urban & $\begin{array}{l}-0.002^{* * * *} \\
{[0.000]}\end{array}$ & $\begin{array}{l}-0.002^{* * * *} \\
{[0.000]}\end{array}$ & $\begin{array}{l}-0.002^{* * *} \\
{[0.000]}\end{array}$ & $\begin{array}{l}-0.002^{* * *} \\
{[0.000]}\end{array}$ & $\begin{array}{l}-0.002^{* * * *} \\
{[0.000]}\end{array}$ & $\begin{array}{l}-0.002^{* * * *} \\
{[0.000]}\end{array}$ & $\begin{array}{l}0.060^{* * *} \\
{[0.004]}\end{array}$ & $\begin{array}{l}0.059^{* * *} \\
{[0.004]}\end{array}$ & $\begin{array}{l}0.060^{* * * *} \\
{[0.004]}\end{array}$ & $\begin{array}{l}0.060^{* * *} \\
{[0.004]}\end{array}$ & $\begin{array}{l}0.060^{* * *} \\
{[0.004]}\end{array}$ & $\begin{array}{l}0.062^{* * *} \\
{[0.004]}\end{array}$ \\
\hline Trade & $\begin{array}{l}-0.001^{* * *} \\
{[0.000]}\end{array}$ & $\begin{array}{l}-0.001^{* * *} \\
{[0.000]}\end{array}$ & $\begin{array}{l}-0.001^{* * *} \\
{[0.000]}\end{array}$ & $\begin{array}{l}-0.001^{* * *} \\
{[0.000]}\end{array}$ & $\begin{array}{l}-0.001^{* * *} \\
{[0.000]}\end{array}$ & $\begin{array}{l}-0.001^{* * *} \\
{[0.000]}\end{array}$ & $\begin{array}{l}-0.006^{* * *} \\
{[0.001]}\end{array}$ & $\begin{array}{l}-0.006^{* * *} \\
{[0.001]}\end{array}$ & $\begin{array}{l}-0.006^{* * *} \\
{[0.001]}\end{array}$ & $\begin{array}{l}-0.006 * * * \\
{[0.001]}\end{array}$ & $\begin{array}{l}-0.006^{* * *} \\
{[0.001]}\end{array}$ & $\begin{array}{l}-0.006^{* * *} \\
{[0.001]}\end{array}$ \\
\hline FDI & $\begin{array}{l}0.001 \\
{[0.001]}\end{array}$ & $\begin{array}{l}0.001 \\
{[0.001]}\end{array}$ & $\begin{array}{l}0.001 \\
{[0.001]}\end{array}$ & $\begin{array}{l}0.001 \\
{[0.001]}\end{array}$ & $\begin{array}{l}0.001 \\
{[0.001]}\end{array}$ & $\begin{array}{l}0.001 \\
{[0.001]}\end{array}$ & $\begin{array}{l}0.011^{* *} \\
{[0.005]}\end{array}$ & $\begin{array}{l}0.011^{* *} \\
{[0.005]}\end{array}$ & $\begin{array}{l}0.011^{* *} \\
{[0.005]}\end{array}$ & $\begin{array}{l}0.011^{* *} \\
{[0.005]}\end{array}$ & $\begin{array}{l}0.011^{* *} \\
{[0.005]}\end{array}$ & $\begin{array}{l}0.010^{* *} \\
{[0.005]}\end{array}$ \\
\hline Cons. & $\begin{array}{l}-2.726^{* * *} \\
{[0.259]}\end{array}$ & $\begin{array}{l}-2.729^{* * *} \\
{[0.259]}\end{array}$ & $\begin{array}{l}-2.719^{* * *} \\
{[0.263]}\end{array}$ & $\begin{array}{l}-2.724^{* * *} \\
{[0.259]}\end{array}$ & $\begin{array}{l}-2.727^{* * *} \\
{[0.258]}\end{array}$ & $\begin{array}{l}-2.681^{* * *} \\
{[0.231]}\end{array}$ & $\begin{array}{l}5.295^{* * *} \\
{[1.545]}\end{array}$ & $\begin{array}{l}5.304^{* * *} \\
{[1.514]}\end{array}$ & $\begin{array}{l}5.388^{* * * *} \\
{[1.584]}\end{array}$ & $\begin{array}{l}5.403^{* * *} \\
{[1.588]}\end{array}$ & $\begin{array}{l}5.482^{* * * *} \\
{[1.569]}\end{array}$ & $\begin{array}{l}6.187^{* * * *} \\
{[1.567]}\end{array}$ \\
\hline Observations & 766 & 766 & 766 & 766 & 766 & 766 & 766 & 766 & 766 & 766 & 766 & 766 \\
\hline $\mathrm{R}$-squared & 0.047 & 0.046 & 0.047 & 0.047 & 0.047 & 0.051 & 0.151 & 0.152 & 0.149 & 0.151 & 0.150 & 0.160 \\
\hline No. of countries & 70 & 70 & 70 & 70 & 70 & 70 & 70 & 70 & 70 & 70 & 70 & 70 \\
\hline
\end{tabular}


Table A3. Excessive entrepreneurship and natural gas rents, forest rents

\begin{tabular}{|c|c|c|c|c|c|c|c|c|c|c|c|c|}
\hline Model: & (1) & (2) & (3) & (4) & (5) & (6) & (7) & (8) & (9) & $(10)$ & (11) & (12) \\
\hline Dep. Var: & \multicolumn{6}{|c|}{ GasR } & \multicolumn{6}{|c|}{ ForestR } \\
\hline Income & $\begin{array}{l}-0.283^{* * *} \\
{[0.081]}\end{array}$ & $\begin{array}{l}-0.281^{* * *} \\
{[0.082]}\end{array}$ & $\begin{array}{l}-0.282^{* * *} \\
{[0.082]}\end{array}$ & $\begin{array}{l}-0.285^{* * *} \\
{[0.081]}\end{array}$ & $\begin{array}{l}-0.285^{* * *} \\
{[0.081]}\end{array}$ & $\begin{array}{l}-0.359^{* * *} \\
{[0.091]}\end{array}$ & $\begin{array}{l}-2.004^{* * *} \\
{[0.076]}\end{array}$ & $\begin{array}{l}-2.005^{* * *} \\
{[0.074]}\end{array}$ & $\begin{array}{l}-2.008^{* * *} \\
{[0.074]}\end{array}$ & $\begin{array}{l}-2.006^{* * *} \\
{[0.076]}\end{array}$ & $\begin{array}{l}-2.008^{* * *} \\
{[0.075]}\end{array}$ & $\begin{array}{l}-2.075^{* * *} \\
{[0.077]}\end{array}$ \\
\hline Income ${ }^{\wedge} 2$ & $\begin{array}{l}0.010^{* *} \\
{[0.004]}\end{array}$ & $\begin{array}{l}0.010^{* *} \\
{[0.004]}\end{array}$ & $\begin{array}{l}0.010^{* *} \\
{[0.004]}\end{array}$ & $\begin{array}{l}0.010^{* *} \\
{[0.004]}\end{array}$ & $\begin{array}{l}0.010^{* *} \\
{[0.004]}\end{array}$ & $\begin{array}{l}0.014^{* * *} \\
{[0.005]}\end{array}$ & $\begin{array}{l}0.095^{* * *} \\
{[0.004]}\end{array}$ & $\begin{array}{l}0.095^{* * *} \\
{[0.004]}\end{array}$ & $\begin{array}{l}0.095^{* * *} \\
{[0.004]}\end{array}$ & $\begin{array}{l}0.095^{* * *} \\
{[0.004]}\end{array}$ & $\begin{array}{l}0.095^{* * *} \\
{[0.004]}\end{array}$ & $\begin{array}{l}0.099^{* * *} \\
{[0.004]}\end{array}$ \\
\hline DUM1 & $\begin{array}{l}\mathbf{0 . 0 2 1} \\
{[0.057]}\end{array}$ & & & & & & $\begin{array}{l}\mathbf{0 . 0 4 9} \\
{[0.056]}\end{array}$ & & & & & \\
\hline DUM2 & & $\begin{array}{l}\mathbf{0 . 0 3 4} \\
{[0.055]}\end{array}$ & & & & & & $\begin{array}{l}0.040 \\
{[0.056]}\end{array}$ & & & & \\
\hline DUM3 & & & $\begin{array}{l}\mathbf{0 . 0 4 9} \\
{[0.049]}\end{array}$ & & & & & & $\begin{array}{l}\mathbf{0 . 0 1 9} \\
{[0.051]}\end{array}$ & & & \\
\hline DUM4 & & & & $\begin{array}{l}-\mathbf{0 . 0 0 3} \\
{[0.052]}\end{array}$ & & & & & & $\begin{array}{l}\mathbf{0 . 0 4 9} \\
{[0.056]}\end{array}$ & & \\
\hline DUM5 & & & & & $\begin{array}{l}-\mathbf{0 . 0 0 1} \\
{[0.051]}\end{array}$ & & & & & & $\begin{array}{l}\mathbf{0 . 0 4 2} \\
{[0.056]}\end{array}$ & \\
\hline DUM6 & & & & & & $\begin{array}{l}\mathbf{0 . 2 8 4} * * * \\
{[0.047]}\end{array}$ & 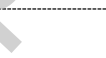 & & & & & $\begin{array}{l}\mathbf{0 . 2 5 1} \text { *** } \\
{[0.031]}\end{array}$ \\
\hline Cap & $\begin{array}{l}-0.015^{* * *} \\
{[0.003]}\end{array}$ & $\begin{array}{l}-0.016^{* * *} \\
{[0.003]}\end{array}$ & $\begin{array}{l}-0.016^{* * *} \\
{[0.004]}\end{array}$ & $\begin{array}{l}-0.015^{* * *} \\
{[0.003]}\end{array}$ & $\begin{array}{l}-0.015^{* * *} \\
{[0.003]}\end{array}$ & $\begin{array}{l}-0.016^{* * *} \\
{[0.004]}\end{array}$ & $\begin{array}{l}-0.018^{* * *} \\
{[0.005]}\end{array}$ & $\begin{array}{l}-0.018^{* * *} \\
{[0.005]}\end{array}$ & $\begin{array}{l}-0.018^{* * *} \\
{[0.005]}\end{array}$ & $\begin{array}{l}-0.018^{* * *} \\
{[0.005]}\end{array}$ & $\begin{array}{l}-0.018^{* * *} \\
{[0.005]}\end{array}$ & $\begin{array}{l}-0.018^{* * *} \\
{[0.005]}\end{array}$ \\
\hline Urban & $\begin{array}{l}0.007^{* * *} \\
{[0.001]}\end{array}$ & $\begin{array}{l}0.007^{* * *} \\
{[0.001]}\end{array}$ & $\begin{array}{l}0.007^{* * *} \\
{[0.001]}\end{array}$ & $\begin{array}{l}0.007^{* * *} \\
{[0.001]}\end{array}$ & $\begin{array}{l}0.007^{* * *} \\
{[0.001]}\end{array}$ & $\begin{array}{l}0.008^{* * *} \\
{[0.001]}\end{array}$ & $\begin{array}{l}-0.002^{* * *} \\
{[0.000]}\end{array}$ & $\begin{array}{l}-0.002^{* * *} \\
{[0.000]}\end{array}$ & $\begin{array}{l}-0.001^{* * *} \\
{[0.000]}\end{array}$ & $\begin{array}{l}-0.002^{* * *} \\
{[0.000]}\end{array}$ & $\begin{array}{l}-0.002^{* * *} \\
{[0.000]}\end{array}$ & $\begin{array}{l}-0.001^{* *} \\
{[0.000]}\end{array}$ \\
\hline Trade & $\begin{array}{l}-0.001^{* * * *} \\
{[0.000]}\end{array}$ & $\begin{array}{l}-0.001^{* * *} \\
{[0.000]}\end{array}$ & $\begin{array}{l}-0.001^{* * *} \\
{[0.000]}\end{array}$ & $\begin{array}{l}-0.001^{* * *} \\
{[0.000]}\end{array}$ & $\begin{array}{l}-0.001^{* * * *} \\
{[0.000]}\end{array}$ & $\begin{array}{l}-0.001^{* * *} \\
{[0.000]}\end{array}$ & $\begin{array}{l}-0.000^{* * *} \\
{[0.000]}\end{array}$ & $\begin{array}{l}-0.000^{* * *} \\
{[0.000]}\end{array}$ & $\begin{array}{l}-0.000^{* * *} \\
{[0.000]}\end{array}$ & $\begin{array}{l}-0.000^{* * *} \\
{[0.000]}\end{array}$ & $\begin{array}{l}-0.000^{* * * *} \\
{[0.000]}\end{array}$ & $\begin{array}{l}-0.000^{* * *} \\
{[0.000]}\end{array}$ \\
\hline FDI & $\begin{array}{l}-0.000 \\
{[0.001]}\end{array}$ & $\begin{array}{l}-0.000 \\
{[0.001]}\end{array}$ & $\begin{array}{l}-0.000 \\
{[0.001]}\end{array}$ & $\begin{array}{l}-0.000 \\
{[0.001]}\end{array}$ & $\begin{array}{l}-0.000 \\
{[0.001]}\end{array}$ & $\begin{array}{l}-0.001 \\
{[0.001]}\end{array}$ & $\begin{array}{l}-0.002^{* *} \\
{[0.001]}\end{array}$ & $\begin{array}{l}-0.002^{* *} \\
{[0.001]}\end{array}$ & $\begin{array}{l}-0.002^{* *} \\
{[0.001]}\end{array}$ & $\begin{array}{l}-0.002^{* *} \\
{[0.001]}\end{array}$ & $\begin{array}{l}-0.002^{* *} \\
{[0.001]}\end{array}$ & $\begin{array}{l}-0.002^{* *} \\
{[0.001]}\end{array}$ \\
\hline Cons. & $\begin{array}{l}2.108^{* * * *} \\
{[0.421]}\end{array}$ & $\begin{array}{l}2.100^{* * * *} \\
{[0.423]}\end{array}$ & $\begin{array}{l}2.093^{* * * *} \\
{[0.421]}\end{array}$ & $\begin{array}{l}2.125^{* * * *} \\
{[0.420]}\end{array}$ & $\begin{array}{l}2.123^{* * * *} \\
{[0.419]}\end{array}$ & $\begin{array}{l}2.307^{* * *} \\
{[0.437]}\end{array}$ & $\begin{array}{l}11.284^{* * * *} \\
{[0.373]}\end{array}$ & $\begin{array}{l}11.294^{* * *} \\
{[0.365]}\end{array}$ & $\begin{array}{l}11.309^{* * *} \\
{[0.367]}\end{array}$ & $\begin{array}{l}11.294^{* * *} \\
{[0.375]}\end{array}$ & $\begin{array}{l}11.304^{* * *} \\
{[0.372]}\end{array}$ & $\begin{array}{l}11.483^{* * *} \\
{[0.365]}\end{array}$ \\
\hline Observations & 766 & 766 & 766 & 766 & 766 & 766 & 766 & 766 & 766 & 766 & 766 & 766 \\
\hline $\mathrm{R}$-squared & 0.040 & 0.041 & 0.041 & 0.040 & 0.040 & 0.074 & 0.222 & 0.222 & 0.222 & 0.222 & 0.222 & 0.239 \\
\hline No. of countries & 70 & 70 & 70 & 70 & 70 & 70 & 70 & 70 & 70 & 70 & 70 & 70 \\
\hline
\end{tabular}

Table A4. Excessive entrepreneurship and oil rents in full sample

\begin{tabular}{|c|c|c|c|c|c|c|}
\hline Dep. var: $\boldsymbol{N R R}$ & (1) & (2) & (3) & (4) & (5) & (6) \\
\hline Income & $\begin{array}{l}6.314^{* * *} \\
{[0.601]}\end{array}$ & $\begin{array}{l}6.307^{* * *} \\
{[0.604]}\end{array}$ & $\begin{array}{l}6.346^{* * *} \\
{[0.560]}\end{array}$ & $\begin{array}{l}6.321^{* * *} \\
{[0.607]}\end{array}$ & $\begin{array}{l}6.322^{* * *} \\
{[0.609]}\end{array}$ & $\begin{array}{l}4.961^{* * *} \\
{[0.542]}\end{array}$ \\
\hline Income $^{\wedge} 2$ & $\begin{array}{l}-0.345^{* * *} \\
{[0.033]}\end{array}$ & $\begin{array}{l}-0.345^{* * *} \\
{[0.033]}\end{array}$ & $\begin{array}{l}-0.347^{* * *} \\
{[0.031]}\end{array}$ & $\begin{array}{l}-0.346^{* * *} \\
{[0.033]}\end{array}$ & $\begin{array}{l}-0.346^{* * *} \\
{[0.034]}\end{array}$ & $\begin{array}{l}-0.271^{* * *} \\
{[0.030]}\end{array}$ \\
\hline DUM1 & $\begin{array}{l}0.072 \\
{[0.279]}\end{array}$ & & & & & \\
\hline
\end{tabular}




\begin{tabular}{|c|c|c|c|c|c|c|}
\hline DUM2 & & $\begin{array}{l}0.094 \\
{[0.294]}\end{array}$ & & & & \\
\hline DUM3 & & & $\begin{array}{l}0.251 \\
{[0.288]}\end{array}$ & & & \\
\hline DUM4 & & & & $\begin{array}{l}0.032 \\
{[0.292]}\end{array}$ & & \\
\hline DUM5 & & & & & $\begin{array}{l}0.019 \\
{[0.283]}\end{array}$ & \\
\hline DUM6 & & & & & & $\begin{array}{l}1.580^{* * *} \\
{[0.326]}\end{array}$ \\
\hline Cap & $\begin{array}{l}-0.023 \\
{[0.017]}\end{array}$ & $\begin{array}{l}-0.023 \\
{[0.017]}\end{array}$ & $\begin{array}{l}-0.024 \\
{[0.017]}\end{array}$ & $\begin{array}{l}-0.023 \\
{[0.017]}\end{array}$ & $\begin{array}{l}-0.022 \\
{[0.017]}\end{array}$ & $\begin{array}{l}-0.029^{*} \\
{[0.017]}\end{array}$ \\
\hline Urban & $\begin{array}{l}-0.033^{* * *} \\
{[0.004]}\end{array}$ & $\begin{array}{l}-0.034^{* * *} \\
{[0.004]}\end{array}$ & $\begin{array}{l}-0.034^{* * *} \\
{[0.004]}\end{array}$ & $\begin{array}{l}-0.033^{* * *} \\
{[0.004]}\end{array}$ & $\begin{array}{l}-0.033^{* * *} \\
{[0.004]}\end{array}$ & $\begin{array}{l}-0.032^{* * * *} \\
{[0.004]}\end{array}$ \\
\hline Trade & $\begin{array}{l}-0.019^{* * *} \\
{[0.003]}\end{array}$ & $\begin{array}{l}-0.019^{* * *} \\
{[0.003]}\end{array}$ & $\begin{array}{l}-0.019^{* * *} \\
{[0.003]}\end{array}$ & $\begin{array}{l}-0.019^{* * *} \\
{[0.003]}\end{array}$ & $\begin{array}{l}-0.019^{* * *} \\
{[0.003]}\end{array}$ & $\begin{array}{l}-0.019^{* * *} \\
{[0.003]}\end{array}$ \\
\hline FDI & $\begin{array}{l}0.033^{* * *} \\
{[0.010]}\end{array}$ & $\begin{array}{l}0.032^{* * *} \\
{[0.010]}\end{array}$ & $\begin{array}{l}0.031^{* * *} \\
{[0.011]}\end{array}$ & $\begin{array}{l}0.033^{* * *} \\
{[0.010]}\end{array}$ & $\begin{array}{l}0.033^{* * *} \\
{[0.010]}\end{array}$ & $\begin{array}{l}0.023^{* * *} \\
{[0.009]}\end{array}$ \\
\hline Cons. & $\begin{array}{l}-22.494^{* * *} \\
{[2.108]}\end{array}$ & $\begin{array}{l}-22.463^{* * *} \\
{[2.134]}\end{array}$ & $\begin{array}{l}-22.689^{* * *} \\
{[1.932]}\end{array}$ & $\begin{array}{l}-22.508^{* * *} \\
{[2.127]}\end{array}$ & $\begin{array}{l}-22.511^{* * *} \\
{[2.130]}\end{array}$ & $\begin{array}{l}-17.219^{\text {*** }} \\
{[2.190]}\end{array}$ \\
\hline Observations & 495 & 495 & 495 & 495 & 495 & 495 \\
\hline $\mathrm{R}$-squared & 0.065 & 0.065 & 0.066 & 0.065 & 0.065 & 0.115 \\
\hline No. of countries & 45 & 45 & 45 & 45 & 45 & 45 \\
\hline
\end{tabular}

Note: standard errors are in $\lceil; * * * * * *$ are significant levels at $10 \%, 5 \%$, and $1 \%$, respectively

\section{Supplementary materials}

Table S1. Excessive entrepreneurship and natural resources rents (robustness check with institutional quality as control variable)

\begin{tabular}{|c|c|c|c|c|c|c|}
\hline Dep. var: $\boldsymbol{N R R}$ & (1) & (2) & (3) & (4) & (5) & (6) \\
\hline Income & $\begin{array}{l}-1.684^{* * *} \\
{[0.484]}\end{array}$ & $\begin{array}{l}-1.686^{* * *} \\
{[0.482]}\end{array}$ & $\begin{array}{l}-1.712^{* * *} \\
{[0.505]}\end{array}$ & $\begin{array}{l}-1.727^{* * *} \\
{[0.492]}\end{array}$ & $\begin{array}{l}-1.761^{\text {*** }} \\
{[0.488]}\end{array}$ & $\begin{array}{l}-2.434^{* * *} \\
{[0.564]}\end{array}$ \\
\hline Income $^{\wedge} 2$ & $\begin{array}{l}0.117^{* * * *} \\
{[0.025]}\end{array}$ & $\begin{array}{l}0.120^{* * *} \\
{[0.026]}\end{array}$ & $\begin{array}{l}0.119^{* * *} \\
{[0.027]}\end{array}$ & $\begin{array}{l}0.120^{* * *} \\
{[0.026]}\end{array}$ & $\begin{array}{l}0.122^{* * *} \\
{[0.026]}\end{array}$ & $\begin{array}{l}0.158^{* * *} \\
{[0.034]}\end{array}$ \\
\hline DUM1 & $0.811^{* *}$ & & & & & \\
\hline DUM2 & & $\begin{array}{l}0.898^{* *} \\
{[0.384]}\end{array}$ & & & & \\
\hline DUM3 & & & $\begin{array}{l}0.827^{* *} \\
{[0.362]}\end{array}$ & & & \\
\hline DUM4 & & & & $\begin{array}{l}0.727^{* *} \\
{[0.333]}\end{array}$ & & \\
\hline
\end{tabular}




\begin{tabular}{|c|c|c|c|c|c|c|}
\hline DUM5 & & & & & $\begin{array}{l}0.734^{* *} \\
{[0.327]}\end{array}$ & \\
\hline DUM6 & & & & & & $\begin{array}{l}2.564^{* * *} \\
{[0.370]}\end{array}$ \\
\hline Cap & $\begin{array}{l}0.053^{* *} \\
{[0.026]}\end{array}$ & $\begin{array}{l}0.048^{*} \\
{[0.026]}\end{array}$ & $\begin{array}{l}0.051^{*} \\
{[0.026]}\end{array}$ & $\begin{array}{l}0.053^{*} \\
{[0.026]}\end{array}$ & $\begin{array}{l}0.053^{* *} \\
{[0.026]}\end{array}$ & $\begin{array}{l}0.048^{*} \\
{[0.027]}\end{array}$ \\
\hline Urban & $\begin{array}{l}0.050^{* * *} \\
{[0.003]}\end{array}$ & $\begin{array}{l}0.048^{* * * *} \\
{[0.004]}\end{array}$ & $\begin{array}{l}0.050^{* * *} \\
{[0.003]}\end{array}$ & $\begin{array}{l}0.050^{* * * *} \\
{[0.003]}\end{array}$ & $\begin{array}{l}0.049^{* * *} \\
{[0.003]}\end{array}$ & $\begin{array}{l}0.055^{* * *} \\
{[0.003]}\end{array}$ \\
\hline Trade & $\begin{array}{l}-0.013^{* * *} \\
{[0.002]}\end{array}$ & $\begin{array}{l}-0.013^{* * *} \\
{[0.002]}\end{array}$ & $\begin{array}{l}-0.013^{* * *} \\
{[0.002]}\end{array}$ & $\begin{array}{l}-0.013^{* * *} \\
{[0.002]}\end{array}$ & $\begin{array}{l}-0.013^{* * *} \\
{[0.002]}\end{array}$ & $\begin{array}{l}-0.013^{* * * *} \\
{[0.002]}\end{array}$ \\
\hline FDI & $\begin{array}{l}0.010^{* *} \\
{[0.005]}\end{array}$ & $\begin{array}{l}0.010^{*} \\
{[0.005]}\end{array}$ & $\begin{array}{l}0.010^{*} \\
{[0.005]}\end{array}$ & $\begin{array}{l}0.010^{* *} \\
{[0.005]}\end{array}$ & $\begin{array}{l}0.010^{* *} \\
{[0.005]}\end{array}$ & $\begin{array}{l}0.006 \\
{[0.005]}\end{array}$ \\
\hline Inst & $\begin{array}{l}-3.119^{* * * *} \\
{[0.356]}\end{array}$ & $\begin{array}{l}-3.139^{* * *} \\
{[0.354]}\end{array}$ & $\begin{array}{l}-3.115^{* * * *} \\
{[0.353]}\end{array}$ & $\begin{array}{l}-3.117^{* * *} \\
{[0.358]}\end{array}$ & $\begin{array}{l}-3.127^{* * * *} \\
{[0.357]}\end{array}$ & $\begin{array}{l}-3.110^{* * *} \\
{[0.367]}\end{array}$ \\
\hline Cons. & $\begin{array}{l}6.274^{* * *} \\
{[2.217]}\end{array}$ & $\begin{array}{l}6.291^{* * *} \\
{[2.166]}\end{array}$ & $\begin{array}{l}6.374^{* * *} \\
{[2.291]}\end{array}$ & $\begin{array}{l}6.489^{* * *} \\
{[2.236]}\end{array}$ & $\begin{array}{l}6.592^{* * *} \\
{[2.214]}\end{array}$ & $\begin{array}{l}8.543^{* * *} \\
{[2.052]}\end{array}$ \\
\hline Observations & 766 & 766 & 766 & 766 & 766 & 766 \\
\hline R-squared & 0.179 & 0.18 & 0.179 & 0.178 & 0.178 & 0.238 \\
\hline No. of countries & 70 & 70 & 70 & 70 & 70 & 70 \\
\hline
\end{tabular}


Table S2. Excessive entrepreneurship and natural resources rents in HIEs (robustness check with institutional quality as control variable)

\begin{tabular}{|c|c|c|c|c|c|c|}
\hline Dep. var: $\boldsymbol{N R \boldsymbol { R }}$ & (1) & (2) & (3) & (4) & (5) & (6) \\
\hline Income & $\begin{array}{l}-52.671^{* * * *} \\
{[2.742]}\end{array}$ & $\begin{array}{l}-51.702^{* * *} \\
{[2.613]}\end{array}$ & $\begin{array}{l}-51.934^{* * *} \\
{[2.450]}\end{array}$ & $\begin{array}{l}-51.935^{* * *} \\
{[2.619]}\end{array}$ & $\begin{array}{l}-52.196^{* * *} \\
{[2.442]}\end{array}$ & $\begin{array}{l}-52.015^{* * *} \\
{[2.537]}\end{array}$ \\
\hline Income $^{\wedge} 2$ & $\begin{array}{l}2.452^{* * *} \\
{[0.133]}\end{array}$ & $\begin{array}{l}2.406^{* * *} \\
{[0.127]}\end{array}$ & $\begin{array}{l}2.416^{* * *} \\
{[0.118]}\end{array}$ & $\begin{array}{l}2.418^{* * * *} \\
{[0.127]}\end{array}$ & $\begin{array}{l}2.428^{* * *} \\
{[0.118]}\end{array}$ & $\begin{array}{l}2.417^{* * *} \\
{[0.122]}\end{array}$ \\
\hline DUM1 & $\begin{array}{l}0.823^{* *} \\
{[0.371]}\end{array}$ & & & & & \\
\hline DUM2 & & $\begin{array}{l}0.587^{*} \\
{[0.305]}\end{array}$ & & & & \\
\hline DUM3 & & & $\begin{array}{l}0.712^{* *} \\
{[0.326]}\end{array}$ & & & \\
\hline DUM4 & & & & $\begin{array}{l}0.798^{* *} \\
{[0.352]}\end{array}$ & & \\
\hline DUM5 & & & & & $\begin{array}{l}0.595^{*} \\
{[0.339]}\end{array}$ & \\
\hline DUM6 & & & & & & $\begin{array}{l}0.854^{* * *} \\
{[0.318]}\end{array}$ \\
\hline Cap & $\begin{array}{l}0.039^{* * *} \\
{[0.015]}\end{array}$ & $\begin{array}{l}0.034^{* *} \\
{[0.014]}\end{array}$ & $\begin{array}{l}0.031^{* *} \\
{[0.013]}\end{array}$ & $\begin{array}{l}0.035^{* * *} \\
{[0.013]}\end{array}$ & $\begin{array}{l}0.038^{* * * *} \\
{[0.014]}\end{array}$ & $\begin{array}{l}0.048^{* *} \\
{[0.019]}\end{array}$ \\
\hline Urban & $\begin{array}{l}0.050^{* * *} \\
{[0.005]}\end{array}$ & $\begin{array}{l}0.051^{* * *} \\
{[0.005]}\end{array}$ & $\begin{array}{l}0.051^{* * *} \\
{[0.005]}\end{array}$ & $\begin{array}{l}0.050^{* * *} \\
{[0.005]}\end{array}$ & $\begin{array}{l}0.051^{* * *} \\
{[0.005]}\end{array}$ & $\begin{array}{l}0.057^{* * *} \\
{[0.005]}\end{array}$ \\
\hline Trade & $\begin{array}{l}-0.016^{* * *} \\
{[0.001]}\end{array}$ & $\begin{array}{l}-0.016^{* * *} \\
{[0.001]}\end{array}$ & $\begin{array}{l}-0.016^{* * *} \\
{[0.001]}\end{array}$ & $\begin{array}{l}-0.017^{* * *} \\
{[0.001]}\end{array}$ & $\begin{array}{l}-0.017^{* * *} \\
{[0.001]}\end{array}$ & $\begin{array}{l}-0.016^{* * *} \\
{[0.001]}\end{array}$ \\
\hline FDI & $\begin{array}{l}0.002 \\
{[0.003]}\end{array}$ & $\begin{array}{l}0.002 \\
{[0.003]}\end{array}$ & $\begin{array}{l}0.002 \\
{[0.003]}\end{array}$ & $\begin{array}{l}0.002 \\
{[0.003]}\end{array}$ & $\begin{array}{l}0.002 \\
{[0.003]}\end{array}$ & $\begin{array}{l}0.002 \\
{[0.003]}\end{array}$ \\
\hline Inst & $\begin{array}{l}3.433^{* * *} \\
{[0.234]}\end{array}$ & $\begin{array}{l}3.383^{* * * *} \\
{[0.228]}\end{array}$ & $\begin{array}{l}3.440^{* * * *} \\
{[0.245]}\end{array}$ & $\begin{array}{l}3.419^{* * * *} \\
{[0.242]}\end{array}$ & $\begin{array}{l}3.443^{* * * *} \\
{[0.239]}\end{array}$ & $\begin{array}{l}3.456^{* * *} \\
{[0.275]}\end{array}$ \\
\hline Cons. & $\begin{array}{l}275.588^{* * *} \\
{[13.817]}\end{array}$ & $\begin{array}{l}270.663^{* * *} \\
{[13.219]}\end{array}$ & $\begin{array}{l}271.933^{* * *} \\
{[12.394]}\end{array}$ & $\begin{array}{l}271.727^{* * *} \\
{[13.204]}\end{array}$ & $\begin{array}{l}273.283^{* * *} \\
{[12.308]}\end{array}$ & $\begin{array}{l}271.702^{* * *} \\
{[12.561]}\end{array}$ \\
\hline Observations & 374 & 374 & 374 & 374 & 374 & 374 \\
\hline R-squared & 0.307 & 0.300 & 0.303 & 0.306 & 0.300 & 0.308 \\
\hline No. of countries & 34 & 34 & 34 & 34 & 34 & 34 \\
\hline
\end{tabular}


Table S3. Excessive entrepreneurship and natural resources rents in LMEs (robustness check with institutional quality as control variable)

\begin{tabular}{|c|c|c|c|c|c|c|}
\hline Dep. var: $\boldsymbol{N R \boldsymbol { R }}$ & $(1)$ & $(2)$ & (3) & $(4)$ & $(5)$ & $(6)$ \\
\hline Income & $\begin{array}{l}-2.909^{*} \\
{[1.705]}\end{array}$ & $\begin{array}{l}-4.016^{* *} \\
{[1.653]}\end{array}$ & $\begin{array}{l}-3.808^{* *} \\
{[1.631]}\end{array}$ & $\begin{array}{l}-3.821^{* *} \\
{[1.621]}\end{array}$ & $\begin{array}{l}-3.376^{* *} \\
{[1.665]}\end{array}$ & $\begin{array}{l}0.650 \\
{[1.983]}\end{array}$ \\
\hline Income $^{\wedge} 2$ & $\begin{array}{l}0.351^{* * *} \\
{[0.103]}\end{array}$ & $\begin{array}{l}0.423^{* * *} \\
{[0.100]}\end{array}$ & $\begin{array}{l}0.410^{* * *} \\
{[0.099]}\end{array}$ & $\begin{array}{l}0.410^{* * *} \\
{[0.097]}\end{array}$ & $\begin{array}{l}0.380^{* * *} \\
{[0.101]}\end{array}$ & $\begin{array}{l}0.096 \\
{[0.111]}\end{array}$ \\
\hline DUM1 & $\begin{array}{l}1.057^{*} \\
{[0.563]}\end{array}$ & & & & & \\
\hline DUM2 & & $\begin{array}{l}0.678 \\
{[0.596]}\end{array}$ & & & & \\
\hline DUM3 & & & $\begin{array}{l}0.651 \\
{[0.584]}\end{array}$ & & & \\
\hline DUM4 & & & & $\begin{array}{l}0.454 \\
{[0.528]}\end{array}$ & & \\
\hline DUM5 & & & & & $\begin{array}{l}0.892^{*} \\
{[0.496]}\end{array}$ & \\
\hline DUM6 & & & & & & $\begin{array}{l}3.308^{* * *} \\
{[0.344]}\end{array}$ \\
\hline Cap & $\begin{array}{l}0.013 \\
{[0.036]}\end{array}$ & $\begin{array}{l}0.015 \\
{[0.035]}\end{array}$ & $\begin{array}{l}0.016 \\
{[0.035]}\end{array}$ & $\begin{array}{l}0.017 \\
{[0.035]}\end{array}$ & $\begin{array}{l}0.015 \\
{[0.035]}\end{array}$ & $\begin{array}{l}-0.016 \\
{[0.040]}\end{array}$ \\
\hline Urban & $\begin{array}{l}-0.025^{* * *} \\
{[0.008]}\end{array}$ & $\begin{array}{l}-0.024^{* * *} \\
{[0.007]}\end{array}$ & $\begin{array}{l}-0.024^{* * *} \\
{[0.007]}\end{array}$ & $\begin{array}{l}-0.024^{* * * *} \\
{[0.007]}\end{array}$ & $\begin{array}{l}-0.023^{* * *} \\
{[0.007]}\end{array}$ & $\begin{array}{l}0.000 \\
{[0.007]}\end{array}$ \\
\hline Trade & $\begin{array}{l}-0.002 \\
{[0.004]}\end{array}$ & $\begin{array}{l}-0.001 \\
{[0.004]}\end{array}$ & $\begin{array}{l}-0.002 \\
{[0.004]}\end{array}$ & $\begin{array}{l}-0.002 \\
{[0.004]}\end{array}$ & $\begin{array}{l}-0.002 \\
{[0.004]}\end{array}$ & $\begin{array}{l}-0.011^{* *} \\
{[0.005]}\end{array}$ \\
\hline FDI & $\begin{array}{l}0.343^{* * *} \\
{[0.092]}\end{array}$ & $\begin{array}{l}0.342^{* * *} \\
{[0.091]}\end{array}$ & $\begin{array}{l}0.340^{* * *} \\
{[0.091]}\end{array}$ & $\begin{array}{l}0.350^{* * *} \\
{[0.094]}\end{array}$ & $\begin{array}{l}0.343^{* * *} \\
{[0.092]}\end{array}$ & $\begin{array}{l}0.327^{* * *} \\
{[0.079]}\end{array}$ \\
\hline Inst & $\begin{array}{l}-5.679^{* * *} \\
{[0.599]}\end{array}$ & $\begin{array}{l}-5.728^{* * *} \\
{[0.608]}\end{array}$ & $\begin{array}{l}-5.720^{* * *} \\
{[0.610]}\end{array}$ & $\begin{array}{l}-5.703^{* * *} \\
{[0.612]}\end{array}$ & $\begin{array}{l}-5.696^{* * *} \\
{[0.596]}\end{array}$ & $\begin{array}{l}-5.213^{* * *} \\
{[0.651]}\end{array}$ \\
\hline Cons. & $\begin{array}{l}3.055 \\
{[7.441]}\end{array}$ & $\begin{array}{l}7.328 \\
{[7.226]}\end{array}$ & $\begin{array}{l}6.486 \\
{[7.176]}\end{array}$ & $\begin{array}{l}6.733 \\
{[7.184]}\end{array}$ & $\begin{array}{l}4.926 \\
{[7.277]}\end{array}$ & $\begin{array}{l}-9.647 \\
{[8.949]}\end{array}$ \\
\hline Observations & 392 & 392 & 392 & 392 & 392 & 392 \\
\hline R-squared & 0.188 & 0.182 & 0.182 & 0.181 & 0.185 & 0.256 \\
\hline No. of countries & 36 & 36 & 36 & 36 & 36 & 36 \\
\hline
\end{tabular}

i This meaning of rent or rent-seeking should be distinguished from Ricardian rent, which is a surplus earning above the costs necessary to till a scarce and fertile land. Even though being used to indicate inefficiency, Ricardian rent is seen as being "above-normal earnings" that remain even if the 
economy is in equilibrium SAUTET, F. 2013. Local and systemic entrepreneurship: solving the puzzle of entrepreneurship and economic development. Entrepreneurship: Theory and Practice, 387. 